\title{
Patent Boxes and the Success Rate of Applications
} WP 20/02

\author{
June 2020
}

\section{Ronald B. Davies, Dieter F. Kogler and Ryan Hynes University College Dublin}




\title{
Patent Boxes and the Success Rate of Applications
}

\author{
Ronald B. Davies* \\ (University College Dublin) \\ Dieter F. Kogler \\ (University College Dublin)
}

and

Ryan Hynes
(University College Dublin)

June 16, 2020

\begin{abstract}
Patent boxes significantly reduce the tax rate applied to income earned from a patent. Existing work finds that those reductions increase the number of patents. That said, not all patents are equally novel. In particular, the patent box encourages the submission of patents of marginal novelty, a selection effect that would reduce the average success rates of patents. At the same time, the increased return to patenting encourages additional effort in application preparation and prosecution, increasing success rates. While this predicts an ambiguous effect, due to lower financing costs, the net impact should be smaller for frequent innovators. We use data from applications to the European Patent Office from 1978 to 2017 and find that the introduction of a patent box increases the average success rate of applications by 4.4 percentage points, with the estimated effect becoming negative for frequent innovators. We further find that this effect is greater when boxes apply only to new innovations and when local development is required to access tax reductions. This suggests that for the frequent innovators, who form the bulk of submissions, patent boxes may indeed be encouraging the submission of marginally-novel applications.
\end{abstract}

JEL classification: H2; O3.

Keywords: Patent Box; Patents; Likelihood of Patent Grant

\footnotetext{
*Email: ronbdavies@gmail.com. We thank James R. Hines, Jr. for useful comments. We acknowledge funding from the International Tax Policy Forum, the European Tax Policy Forum, and the European Research Council under the European Unions Horizon 2020 research and innovation programme (grant agreement No 715631, ERC TechEvo). All errors are our own.
} 


\section{Introduction}

Even as governments move to close down some methods firms use to reduce tax burdens they continue to open new ones. One example of this is the introduction of "patent boxes". Under this policy, corporate income attributable to qualifying intellectual property (e.g. a patent) is taxed at a lower rate, often half that of the headline corporate income tax rate. While some nations such as Ireland and France have used patent boxes for decades, a wave of countries introduced new boxes in the years surrounding 2010. To date, the economic literature has largely focused on what the introduction of a patent box does to the number of patents in a country. ${ }^{1}$ Examples here include Alstadsaeter, et al. (2018), Schwab and Todtenhaupt (2016), Griffith, et. al (2014), Becker, Fuest, and Riedel (2012), and Karkinsky and Riedel (2012). On the whole, this work tends to find that a reduction in the tax rate via the patent box leads to more granted patents.

Largely unexplored, however, is what patent boxes do to the quality of patents. An exception here is Ernst, et al. (2014), who use a composite measure of quality and find that lowering corporate taxes via a patent box increases patent quality. All of the this work, however, focuses on granted patents and implicitly assumes that all successful innovations are patented. In fact, this is not the case. In our data, which covers applications to the European Patent Office (EPO) from 1978-2017, only 54\% of applications are granted. ${ }^{2}$ Thus the patenting process is highly uncertain. What is certain, however, is that applying for a patent is costly and includes the filing fee as well as fees for the patent lawyers who are used to prepare the application. ${ }^{3}$ Thus, a firm will only apply if it believes that the expected

\footnotetext{
${ }^{1}$ As detailed below, the number of "patents" can be the number of applications, granted patents, transfers from one country to another, or registrations in EPO members depending on the study.

${ }^{2}$ Similarly, Carley, Hegde, and Marco (2015) report that from 1996-2013 only 55.8\% of US patent applications were granted. Webster, et al. (2014) provide a comparison across the US, Japanese, and European patent offices.

${ }^{3}$ Note that this includes both the initial application as well as potential revisions. First drafts of patent applications are rarely accepted as-is, with the examiner making objections (office actions) to all or part of the patent claims based on the relevant prior art. This requires a revision and resubmission which takes additional legal advice.
} 
benefit of doing so outweighs the costs. ${ }^{4}$ As discussed by the European Commission (2014), the cost of protection can be significant and easily exceed $€ 100,000$. $^{5}$

When a patent box comes into force, this increases the after-tax value of holding a patent (even if the innovation has already been created). Because of this, a patent box can have two conflicting effects on the probability of success, one at the intensive margin and the other at the extensive margin. First, it encourages more effort on preparing the application. This effect on the intensive margin increases success rates. Second, it alters the decision of whether to submit an application at all. In particular, the patent box encourages the submission of applications for innovations that, due to their low novelty and small chance of being granted, otherwise would not have been submitted. This latter concern has been raised by the OECD (2016) and Bradley, et al. (2015) among others. This impact at the extensive margin then lowers the average success rate. Therefore even as the number of applications and granted patents rise, the average success of applications can rise or fall depending on which effect dominates. That said, the net effect of the patent box should be falling in firm size. This arises because the costs of both innovation and application must be paid before the patent is granted (if it even is). If larger firms have deeper cash reserves and/or superior borrowing terms, this would reduce the total application cost as well as the marginal cost of application quality. ${ }^{6}$ The OECD (2016) notes that income-based incentives such as patent boxes may therefore be less useful in spurring innovation by small firms due to the relative

\footnotetext{
${ }^{4}$ Peeters and van Pottelsberghe (2006) find that the decision on whether or not to patent can also depend on the type of a firm's R\&D, that is, whether it is basic or applied research and whether the innovations are product or process.

${ }^{5}$ When patenting with the EPO, the cost of protection includes the submission fee to the EPO and additional registration and translation fees in the member states where protection is desired. They estimate that to patent in thirteen members via the EPO costs $€ 22,472$. Harhoff, et al. (2009) find that translation costs significantly affect registrations. Alstadsaeter, et al. (2018) find that patent boxes do as well. Finally, to maintain protection, subsequent maintenance costs in those thirteen members is estimated at another $€ 93,243$. Indeed, these costs led to the development of a single, multi-country unitary patent system in the European Union with the EPO is set to commence at the end of 2020. See EPO (2017) for details. Note that these figures still do not account for the potential costs from disclosing a firm's proprietary knowledge in the application (see Hall, et al. (2014) for discussion).

${ }^{6}$ Egger and Keuschnigg (2015) present a model in which larger firms invest optimally in R\&D due to their deeper cash reserves and superior access to bank finance, with smaller firms forced to venture capital markets.
} 
difficulty those firms have in obtaining access to financing.

We contribute to the literature by using EPO data to estimate the effect of a patent box on the probability of success and how that varies across applicants. We find that, on average, the patent box increases the probability of granting (also known as the allowance rate) by 4.4 percentage points, nearly a $10 \%$ increase. At the same time, the effect is markedly smaller for frequent innovators and even negative for the most active innovators. Since those latter firms make up a disproportionate share of applications, this suggests a significant potential for the worries expressed by the OECD (2016). Furthermore, we find starker results in narrow patent boxes (where incentives are only available to new patents) and those with nexus requirements (which require local development of the patented innovation to avail of tax reductions). ${ }^{7}$ This latter finding is most attributable to large innovators and suggests the relocation of lucrative, highly successful R\&D projects to low-tax locations. Given the costs involved in the application process, not just to applicants but also for the patent offices, understanding the potential wasted effort on marginally novel innovations is worth recognizing when evaluating the benefits of patent boxes. Further, our results provide a unique insight into potential profit shifting because of patent boxes.

Our results bridge two bodies of research. The first focuses on taxation and innovation and the second on the success rates of patent applications. We discuss each literature and our contributions to them in turn below. The work on taxation and innovation has two main themes, one on the effect of taxes on the level of innovation, with patents being one measure of R\&D, and the other on the location of innovation with a specific focus on the transfer of patents within the multinational. ${ }^{8}$ Overall, the consensus is that lower taxation increases the amount of innovation and that multinationals shift intellectual property to

\footnotetext{
${ }^{7}$ As discussed in detail by Alstadsaeter, et al. (2018) nexus requirements are typically based on expenses attributed to the development of the innovation with a sufficiently high share of those costs needed for the patent to qualify for the box.

${ }^{8}$ Measuring innovation by the number of patents is common and includes Blundell et al. (1995), Stiebale (2016), and much of the literature we cite. That said, it must be remembered that not all innovation leads to a patent application and that granted patents are a subset of even that. As discussed by Hall, et al. (2014) there are a number of issues that go into the strategic decision to apply for a patent making it only an approximate measure of innovative activity.
} 
low tax jurisdictions in order to reduce their global tax burden. ${ }^{9}$ It is important to note that part of the debate regarding the tax treatment of innovation has been a comparison of expenditure-based tax incentives versus income-based incentives. The first of these operates by lowering the tax burden on qualifying expenditures, for example through tax credits for R\&D expenditures. This lowers the cost of innovation and is often measured by the "bindex" a measure capturing the marginal tax on R\&D expenditures (see Bösenberg and Egger (2017) for discussion). Income-based incentives, which include patent boxes, instead operate by lowering the tax on the income from qualifying $R \& D$. This raises the after-tax benefit of innovation rather than lowering its after-tax cost. ${ }^{10}$ One feature of this difference is that income-based incentives only come into play following a successful, marketable innovation. As such, the benefits of income-based incentives accrue much later than expenditure-based ones. Indeed, the OECD (2016) notes that income-based incentives may be less useful for small firms due to their relative difficulty in obtaining access to financing.

Focusing on the literature explicitly considering patent boxes, the standard approach for estimating the impact on the level of innovation is to estimate the number of patents per year across firms or countries. Examples operating at the country-level include Bösenberg and Egger (2017) and Bradley, et. al (2015); firm-level studies include Schwab and Totenhaupt (2019), Alstadsaeter, et al. (2018), and Ernst and Spengel (2011). ${ }^{11}$ Note that one of the key contributions of the firm-level approach is the ability to combine patent information with firm level datasets (e.g. Bureau Van Dijk's Orbis dataset). ${ }^{12}$ While this firm-matched data can be useful, it is generally only available for sufficiently large firms and fails to capture the activities of smaller innovators. Further, even with larger firms, it is often plagued by

\footnotetext{
${ }^{9}$ Examples of work in this vein that do not focus on patent boxes per se would include Karkinski and Riedel (2012) who look at the number of firm-level filings as a function of local taxes or Dischinger and Riedel (2011) who look at the influence of taxes on the location of intangible assets in a multinational.

${ }^{10}$ Intellectual property boxes can more generally extend tax reductions to income earned from trademarks, copyrights, and other types of intangible assets. Patent boxes specifically require a registered patent in order to obtain the tax benefit.

${ }^{11}$ In addition, Mohnen, et al. (2017) find that boxes increase R\&D spending while Chen, et al. (2019) find that they increase both fixed investment and employment.

${ }^{12}$ In a similar disaggregated fashion, Gaessler, et al. (2019) consider the number of inventor filings in a given country-year.
} 
missing data. Finally, matching firm ad patent data leads to matching success rates that vary by country, potentially biasing the estimates. On the whole, the results suggest that patent boxes, which increase the after-tax return to innovation, increase patenting activity. ${ }^{13}$ This is not, however, universal. Bradley, et al. (2015) find that on average there is no effect, although they do find a positive effect when the inventor and applicant are from the same country. Gaessler, et al. (2019), meanwhile, find a weak negative impact. ${ }^{14}$

Setting aside the issue of the amount of patenting, taxes also influence the location of patents within a multinational. Since income attributed a patent is taxable in the country where the patent is held, this gives a multinational an incentive to shift patents to affiliates located where such income incurs a low tax, such as a tax haven or patent box country. ${ }^{15}$ Examples here include Gaessler, et al. (2019), Bösenberg and Egger (2017), Ciaramella (2017), Böhm, et al. (2015), and Griffith, et al. (2014). All of these find that a firm is more likely to either do innovation in a country with a patent box and/or transfer its patents into that country. ${ }^{16}$ This latter possibility in particular provides support for patent box nexus requirements which require local $R \& D$ expenses in order to take advantage of the patent boxes since local R\&D activities arguably generates more local spillovers than imported innovations.

In constructing their data sets, the above studies vary in several important dimensions and it is important to recognize those to understand our contribution. First, none of these consider the probability of a given application being granted which is the focus of our study. Second, the bulk of the above literature uses only granted patents. ${ }^{17}$ While this can easily

\footnotetext{
${ }^{13}$ Further, Schwab and Totenhaupt (2019) find that innovation in one country can by influenced by patent boxes elsewhere when nations are connected via multinational investments.

${ }^{14}$ In addition, the IMF (2016) finds a mixed effect of a patent box on total R\&D using a synthetic control method approach).

${ }^{15}$ Rather than focus on the transfer of intellectual property, Koethenbuerger, et al. (2019), Chen, et al. (2019), and Ludwig (2018) examine profitability within MNE affiliates and find that they are higher in patent box countries. Combined with the patent transfer results, this suggests that not only is intellectual property being located in low-tax countries, but that this enables significant profit shifting.

${ }^{16}$ Ciaramella, et al. (2017) estimates that $60 \%$ of transfers happen pre-granting with Gaessler (2016) suggesting that unofficial indications of likely success influences pre-granting transfers.

${ }^{17}$ This includes Schwab and Totenhaupt (2019), Alstadsaeter, et al. (2018), Ciaramella (2017), Böhm, et al. (2015), and others. Note that while many describe their data as applications (since it is important to
} 
be justified in those studies looking at the location of patents or the registration of a granted patent across countries, it does limit the measure of the level of innovative activity since not all R\&D leads to a patent application, much less a successful one. In contrast, we include both successful and unsuccessful applications. A third difference across studies is the patent offices they consider. While some, e.g. Alstadsaeter, et al. (2018) and Bösenberg and Egger (2017) focus on EPO patents, others such as Bradley, et al. (2015) use a variety of offices. While multiple offices is a virtue for some questions, for our purposes including multiple offices can introduce undue noise if standards vary across offices and time as is found by Webster, et al. (2014) among others.

The second strand of the literature we contribute to is that estimating the likelihood that a patent application is granted. A primary feature of this work is to attempt to control for the quality of an innovation. ${ }^{18}$ This motivates the inclusion of controls including the numbers of inventors, number of claims, technology classes an application covers, and offices to which the same innovation is submitted (family size), all of which are presumed positively correlated with quality. ${ }^{19}$ Indeed, they are generally found to be positively correlated with the probability of success. ${ }^{20}$ While these characteristics act as controls, the focus of these investigations is often elsewhere. A major area of concern is the role nationality plays, particularly "home bias" in which applicants or inventors from the territories covered by the patent office have a higher success rate. Indeed, home bias is found by Drivas and Kaplanis (2020), Webster, et al. (2014), Webster, et al. (2007), Guellec and van Pottelsburghe (2000), and more. Further, applications with international inventor teams and those where the applicant and inventor are from different countries also tend to find higher success rates use the filing date of the application to judge the applicability of a patent box), they limit themselves to applications that are eventually granted. Bradley, et al. (2015) and Ernst and Spengel (2011) are exceptions to this.

${ }^{18}$ In addition to the studies mentioned here, other examples include de Rassenfosse, et al. (2016) and de Rassenfosse, et al. (2017).

${ }^{19}$ van Zeebroeck, et al. (2009) caution on some measures of application quality, noting in particular that the number of claims and length of applications has grown over time as savvy applicants pad their application with sacrificial lambs they expect to lose during the application process.

${ }^{20}$ Kabore and Park (2019) find that weighting the patent family size by the markets covered by an office increase the measures predictive power when estimating the number of citations and patent renewal. 
(see, e.g. Drivas and Kaplanis, 2020). This latter result may be another indicator of quality since such combinations are relatively costly they will be undertaken only when there is a significantly large benefit in doing so.

In addition, a handful of papers focus on the role of the patent law firm, also known as the agent, in the granting process. ${ }^{21}$ While the use of patent attorneys is essentially universal in preparing an application, as in other venues, the impact a given legal team has on the success of an application can depend on their quality and the hours they dedicate to a given application. For example, de Rassenfosse, et al. (2018) split patent data to estimate a law firm fixed effect (average success rate for that firm) on a subsample of the data and used that fixed effect as a control when estimating the probability of success in the remaining data, finding that success in half the data predicts success in the other. One important insight from this literature is the finding that applications using an internal legal team (i.e. where the team is in-house) have higher predicted success rates than when the legal team is employed externally (see de Rassenfosse, et al., 2018). This could be in part due to the legal team's expertise in the science around the innovation, permitting them to construct a more convincing application. In addition, since the goal of an external team is to extract fees from the applicant, one would expect that the marginal cost of having an internal team work on an application is lower (even as the fixed cost is higher). Thus, this would suggest that larger, more frequent applicants are more likely to pay the fixed costs to establish a team of internal patent attorneys, a notion consistent with the evidence of Süzeroglu-Melchiors, et al. (2017), and therefore have higher success rates (consistent with our findings). ${ }^{22}$

While we follow this literature in the choice of our control variables, note that none of

\footnotetext{
${ }^{21}$ See Reitzig (2004) or Hall and Ziedonis (2001) for useful descriptions of the role of the attorney in the process. In addition, Reitzig (2004) looks at the impact the attorney has on whether a patent is opposed post-granting.

${ }^{22} \mathrm{~A}$ small number of studies focus on the role of the patent examiner (the patent office employee who makes the granting decision). Lemley and Sampat (2012) find that more experienced examiners are more likely to grant a patent. Lei and Wright (2017) and Frakes and Wasserman (2016) meanwhile find that examiner effort has an impact on success rates of the applications they consider. These studies use US patent data rather than EPO data as the latter does not provide examiner information which prohibits us from controlling for the examiner.
} 
these considers taxation. If taxes affect the quality of applications (either via the novelty of submitted innovations or the efforts put into the application itself), then changes in tax policy may have a significant effect on success rates. Estimating this is our primary contribution to this second strand of the literature.

The paper proceeds as follows. Section 2 lays out a simple model of innovation and the decision of whether or not to apply for a patent. Section 3 describes our data and empirical approach. Section 4 discusses our results. Section 5 concludes.

\section{A model of innovation and patent application}

To formalize the above argument, consider the following simplified model of arriving at a patented innovation. In the first stage, the firm develops a number of innovations $M$, incurring a development cost $d(M ; s)$ which is increasing and convex in the number of innovations and decreasing in a "size" parameter $s$. The rationale for including size in the cost function is that larger firms have better access to funding. Since R\&D costs are incurred before the fruits of the research are brought to market and revenues can be earned, innovative activities need to be funded by borrowing and/or existing operating capital. Because larger firms have better access to credit (see Angori, et al. (forthcoming) for a recent review) and deeper reserves, we believe this is a reasonable assumption. ${ }^{23}$ Each innovation has a level of novelty $n$ which has a lower bound of zero and is drawn from a differentiable distribution function $F(n)$. The notion behind this is that some innovations are groundbreaking, some are moderately so, and some are rehashes of the existing stock of knowledge.

With these innovations in hand, the firm decides which to attempt to patent. The cost of doing so is a function $c(e ; s)$ per application. This depends on the effort $e$ put into the application, which is increasing and convex in effort. This represents features such as the number of hours and quality of the legal team that prepares the application. As with our

\footnotetext{
${ }^{23}$ Further, as shown below, this predicts larger firms will do more R\&D which matches the empirical results of e.g. Shefer and Frenkel (2005).
} 
assumption on development costs, we assume that $c_{s}<0, c_{e s}<0$, and $c_{e e s}<0$ so that larger firms have lower application costs which grow more slowly as effort rises. In addition to the financing argument above, this can be justified if larger firms are themselves more familiar with the application process, can negotiate better fee schedules with patent law offices, and/or they have their own internal legal team. ${ }^{24}$

Consistent with patent regulations, to be granted a patent, the innovation must be deemed sufficiently novel by the patent examiner. Thus, the probability that an innovation with novelty $n$ would be successful in the patenting process is $p(n, e)$ which is increasing and concave in both arguments, i.e. a more novel innovation and greater effort both increase the chance of success. Further, we assume that $p_{n e}<0$ so that more effort improves the chances of a less-novel innovation more than a more novel one. This is consistent with the results of de Rassenfosse, et al. (2018) who conclude that a more successful legal team does more to boost the success of a low-quality patent than a high-quality one. Note that this probability function allows for randomness in the application process due to the patent examiner's need to decide whether an application meets the subjective threshold of novelty. ${ }^{25}$

If the firm does not hold a patent on a given innovation, either because it does not apply for one or its application is rejected, there is a probability $1-q$ that its innovation is appropriated by a competitor and it earns no taxable profit from the patent. ${ }^{26}$ If this does not happen, it earns $r$ net of production costs which is taxed at the standard tax rate $t .{ }^{27}$ Thus, expected after-tax profit generated from an innovation that for which no application is made is $q(1-t) r$ while that from a failed application is $(1-t)(q r-c(e ; s))$.

If the firm applies for the patent and is successful, then $q=0$. Furthermore, the revenues

\footnotetext{
${ }^{24}$ As discussed by de Rassenfosse, et al. (2018), an external team is aiming to extract rents from the firm which can lead to higher costs.

${ }^{25}$ In practice, both Type I and Type II errors occur in the granting decision. de Rassenfosse, et al. (2016) define type II errors as an application granted by one office yet rejected by another. They find that although these occur, they happen less than $10 \%$ of the time. Frakes and Wasserman (2016) also discuss "bad" patents. The novelty threshold for the EPO is described at https ://www .epo.org/law-practice/legal-texts/html/guidelines/e/g_iv.htm.

${ }^{26}$ This amounts to assuming that appropriation occurs before the firm incurs production costs.

${ }^{27}$ For the sake of simplicity, here we treat $r$ as independent of the level of novelty. If this is increasing in $n$, then it remains the case that the most novel innovations lead to applications.
} 
earned from the patent are taxed within the patent box where the rate is $b t$ with $b<1$. In practice, $b$ is commonly 0.5 . This results in after-tax profits from the innovation of $(1-b t) r-(1-t) c(e ; s)$. Note that this follows the practice of, for example, the Belgian patent box regime in which application and development costs are deductable at the standard tax rate, not that under the patent box. In contrast, under the French system, development costs are deductable only at the reduced rate. For the purposes of this simple model, the Belgian regime is useful because it sidesteps the need to decompose the non-linear interactive $\operatorname{costs} d(n)$ into those that were incurred by successful patent applications and non-patented innovations for tax purposes, an issue which has all the difficulties found in transfer pricing regulation. ${ }^{28}$ With this in mind, for each innovation the firm decides whether to apply for a patent and, if so, the effort to put into the application. If the firm applies, expected profits are given by:

$$
\begin{array}{r}
\pi^{e}(n, a, s)=p(n, e)((1-b t) r-(1-t) c(e ; s))+ \\
=(1-p(n, e))(1-t)(q r-c(e ; s)) \\
=(1-t)(p(n, e) \phi r+q r-c(e ; s))
\end{array}
$$

where $\phi=\frac{1-b t}{1-t}-q$ can be interpreted as the gains from patenting which stem from both the tax savings and the elimination of appropriation. Note that $\frac{d \phi}{d b}=\frac{-t}{1-t}<0$, i.e. as when $b$ falls due to the implementation of a patent box, this increases the gains from patenting. Further, note that the standard tax $t$ only influences $\phi$ if $b<1$. This is because, in the absence of a box, taxes do not distort behaviour. With a box, however, a rise in $t$ increases the gains from patenting precisely because the same $b$ means a bigger percentage point reduction in the effective tax rate inside the box. Thus, the standard tax influences the incentive to patent only because it influences the tax reduction achieved by the box.

From Equation 1, for a given novelty, the optimal effort spent on the application, $e^{*}(n)$

\footnotetext{
${ }^{28}$ In practice, the need to identify qualifying income and, when nexus requirements are part of the box, allocate research costs to patents creates costs for using the box. The results of den Hertog, et al. (2016) however suggest that these costs are negligible and we therefore ignore them here.
} 
is determined when the marginal benefit equals the marginal cost, i.e.:

$$
p_{e}\left(n, e^{*}(n)\right) \phi r=c_{e}\left(e^{*}(n) ; s\right) \text {. }
$$

From this, three key results can be found for a given novelty. First:

$$
\frac{d e^{*}}{d \phi}=-\frac{p_{e}}{p_{e e} \phi r-c_{e e}}>0
$$

i.e. as the gain from patenting rises (such as occurs with the introduction of a patent box), more effort is put into an application. Second,

$$
\frac{d e^{*}}{d s}=\frac{c_{e s}}{p_{e e} \phi r-c_{e e}}>0
$$

which means that larger firms will put more effort into an application. To see the third, first define two elasticities: $\eta=\frac{e\left(p_{e e e} \phi r-c_{e e e}\right)}{p_{e e} \phi r-c_{e e}}$ (the elasticity of effort's second order condition with respect to effort) and $\varepsilon=\frac{e c_{e e s}}{c_{e s}}>0$ (the elasticity of the effect of size on marginal effort costs with respect to effort). We can then write:

$$
\frac{d^{2} e^{*}}{d \phi d s}=\frac{-1}{\left(p_{e e} \phi r-c_{e e}\right)}\left(\frac{p_{e}}{e^{*} c_{e s}}(\varepsilon-\eta)+c_{e s} p_{e e}\right)
$$

which is in general ambiguous. That said, so long as $\varepsilon$ is not too much larger than $\eta$, then $\frac{d^{2} e^{*}}{d \phi d s}<0$, i.e. the responsiveness of effort to a change in the gain from patenting is smaller for larger firms. ${ }^{29}$ Since in a study of Dutch firms den Hertog, et al. (2016) find that smaller firms are more apt to take advantage of a patent box, suggesting that a change in $b$ affects small firms more, this might be a reasonable assumption.

Knowing the effort it would then put into an application, the firm must decide whether or not to apply. It will do so whenever the expected profit from application is at least as large as when it does not apply, i.e. when $p\left(n, e^{*}\right) \phi r-c\left(e^{*} ; s\right) \geq 0$. This then points to

\footnotetext{
${ }^{29}$ In a similar way, we can show that $\frac{d^{2} e^{*}}{d \phi d s}<0$
} 
a cutoff novelty level $\bar{n}$ for which the firm is indifferent between applying and not applying where, for $n>\bar{n}$ the firm applies. From this, it is straightforward to show that:

$$
\frac{d \bar{n}}{d \phi}=\frac{p}{p_{n} \phi}>0
$$

so that introducing a patent box lowers the novelty threshold, meaning that firms would seek applications for more innovations even if the number of innovations does not change. Further, the additional submissions will be for innovations of marginal novelty. This selection effect of patent boxes is raised as a potential concern by the OECD (2016) and Bradley, et al. (2015). ${ }^{30}$ In addition, applying the envelope theorem for the change in optimal effort, we see that:

$$
\frac{d^{2} \bar{n}}{d \phi d s}=\frac{1}{p_{n} \phi}\left(p_{e}-\frac{p p_{n e}}{p_{n}}\right) \frac{d e^{*}}{d s}>0
$$

i.e. a larger firm's cutoff will respond more to the patent box than that of a smaller firm.

With these results in hand, we can now turn to the impact of a patent box on the success rate of patents. For applications that would have been submitted even without the patent box, the box increases effort and therefore the probability of success for that set of innovations (an intensive margin effect). In addition, the box induces the submission of marginally novel applications which will have lower average success than that first group of "existing" applications (an extensive margin effect). Taken together, the impact on the average success rate at the firm level is ambiguous and depends not just on the size of these two effects, but also on the distribution of novelties (which will affect the number of new applications in comparison to the number of "existing" ones). That said, whatever the sign of the net effect, we expect that it should be less for larger firms. This arises because for larger firms the introduction of the patent box leads both to a smaller increase in effort (i.e. a smaller rise in average success for the existing patents) and a larger fall in the novelty

\footnotetext{
${ }^{30}$ Although somewhat different, it also relates to the potential for unused "zombie" patents discussed by Gaessler, et al. (2019).
} 
cutoff (i.e. the introduction of more applications with low success rates). These are the primary predictions we take to the data.

Turning to the standard tax rate $t$, recall that in the absence of a box, it does not influence effort nor the novelty cutoff. With a box, the corporate tax has an effect but only because it affects the benefit of the box. Therefore we do not expect a significant effect of the standard tax rate on the success of applications. Although not modeled, we could introduce the b-index as affecting the net cost of performing $\mathrm{R} \& \mathrm{D} d(M ; s)$ (which differs from the application cost). Nevertheless, this would not impact effort nor the decision of which innovations to submit for patenting. Therefore, we do not expect the b-index to affect the success rate.

Finally, the above analysis takes the number of innovations $M$ as given. Since the introduction of the patent box (a reduction in $b$ ) increases the expected after-tax value of generating innovations, it should increase the number of innovations generated for firms of all sizes. Thus, the number of aggregate applications should rise both because of more research is done by firms (a rise in $M$ ) and because more innovations are submitted. This would then match the evidence provided by Schwab and Todtenhaupt (2019), Alstadsaeter, et al. (2018), and others. ${ }^{31}$

\section{Data and Estimation Strategy}

In this section, we first describe our data which contains two main components: patent application data (which largely drives the country and year coverage in our data) and country data (including tax information, especially patent boxes). We then lay out our strategy for estimating the probability of a given application being granted.

\footnotetext{
${ }^{31}$ In addition Balasubramanian and Sivadasan (2011) find that firms grow after patenting. Agiakloglou, Drivas, and Karamanis (2016) find that larger firms are also more likely to renew an existing patent whereas smaller firms are more apt to transfer ownership.
} 


\subsection{Patent Data}

We use bibliographic patent data from the European Patent Office (EPO) PATSTAT database for patent applications to the EPO filed from 1978 to 2017. Each application provides the name and country of the applicant(s), the name and country of the inventor(s), the application filing date, the date the application was granted (if it has been), and the technology codes assigned to the application by the EPO (more on these below). This leaves us with $3,257,833$ "A" patent applications, of which $54.4 \%$ were granted at some point during the sample period (the success rate). ${ }^{32}$

Our goal is to construct the cleanest sample we can to improve identification. With this in mind, we restrict ourselves to those patents where all applicants come from the same country. ${ }^{33}$ We do so to eliminate noise arising from patents where the ownership - and thus the tax jurisdiction - may cross borders adding to difficulties in interpreting which tax policies are important for application behaviour. ${ }^{34}$ This eliminates 68,684 patents (or $2.11 \%$ of the sample). ${ }^{35}$ In order to further eliminate excess noise from the sample, we restrict ourselves to only those applicants from EPO member countries. ${ }^{36}$ This reduces our number of applications by $1,688,516$ or $52.9 \%$. This is a large reduction, but as is well known there is a significant home bias in terms of patenting (i.e. applicants are far more likely to apply in their own country than in others). In addition, as discussed above, there is a significant home

\footnotetext{
${ }^{32}$ The success rate is also known as the allowance rate.

${ }^{33}$ Note that the applicants are the owner of the innovation (many times a firm) and therefore often differ from the inventors (who are humans). This also avoids the need for fractional apportionment of crosscountry applications as was done by Bradley, et al. (2015) when calculating the total number of applications by country-year. It should be noted that while the bulk of the literature, ourselves included uses the applicant to assign an application to a country. Since income from an innovation arguably accrues to the applicant rather than the inventor, this seems apt when examining taxation. That said, Bösenberg and Egger identify country by the inventor rather than the applicant.

${ }^{34}$ Ernst and Spengel (2011) and Schwab and Todtenhaupt (2016) find evidence consistent with multinational firms shifting innovation activities across borders for tax purposes, further bolstering our reasons for this restriction.

${ }^{35}$ Note that the success rate of cross-country applications is $55.7 \%$, slightly higher than for single country applications.

${ }^{36}$ This includes the EU member states during any point of our sample period, Switzerland, Croatia, Monaco, Macedonia, Norway, Turkey, Albania, Bosnia and Herzegovina, Serbia, and Montenegro.
} 
bias in terms of the success rates. ${ }^{37}$ Indeed, in our data, the success rate of EPO member applications is $59.0 \%$ whereas that for non-members is only $50.2 \% .^{38}$ Due to missing tax data (described below), we also drop six EPO members, resulting in a loss of 5,404 additional applications. ${ }^{39}$ This leaves us with a total of 1,499,988 applications. Out of these, $96.2 \%$ of applications have a single applicant (with another $3.2 \%$ having two applicants). As the success rate for multi-applicant applications is markedly lower (53.8\% as opposed to $59.3 \%$ for solo-authored ones) we restrict ourselves to the 1,442,695 solo applications.

We construct several pieces of information from these applications. First, for each applicant, we construct the total number of applications they made during the data period (1978-2017). ${ }^{40}$ We do so using the entire time span of 1978 to 2017, not only during our estimation window of 2000-2012. Even though the sample includes over 1.4 million applications, these are made by only 292,820 applicants. The average number of applications by a single applicant is 4.93 , with $63.3 \%$ making a single application and $94.9 \%$ making ten or less. ${ }^{41}$ Thus, the small number of frequent applicants account for a large fraction of the total applications. ${ }^{42}$ Further, those frequent applicants have better success rates. ${ }^{43}$ For those with a single application, $48.2 \%$ of applications are granted. For those between two and ten applications, this rises to $61.6 \%$ whereas those with more than ten applications are successful $72.8 \%$ of the time. ${ }^{44}$ Thus, experience appears to have a significant effect on success. With

\footnotetext{
${ }^{37}$ Home bias in patenting extends even further to include a bias in citations (Bacchiocchi and Montobbio, 2010).

${ }^{38}$ Note that this is unlikely driven by differences in when applications are occurring as the average filing date of non-member applications is less than a year after that of member applications.

${ }^{39}$ These were Albania (38 applications), Bosnia and Herzegovenia (85), Macedonia (25), Monaco (4,710), Montenegro (18), and Serbia (528).

${ }^{40}$ Note that the applications do not assign specific identification numbers to applicants or inventors. In order to match an applicant or inventor across applications, they were matched when the name, address, and country were the same. When this was not possible, we employed the Massacrator 2.0 algorithm, as described in Pezzoni, Lissoni, and Tarasconi (2013).

${ }^{41}$ Even when an applicant makes numerous applications across years, rarely are several applications made in a single year. For applicants that have more than ten applications in across all years, $32.0 \%$ of the time they make a single application per year and $19.6 \%$ of the time they make only two in a given year.

${ }^{42}$ In the estimation sample, those making more than ten applications from 1978 to 2017 account for $67.4 \%$ of our applications. The most by a single applicant is 27,645 .

${ }^{43}$ This mirrors the evidence of Carley, et al. (2015) for US applications.

${ }^{44}$ Focusing on our estimation window of 2000-2012 which has 721,982 applications, we have 148,991 applicants. On average, these applicants make 6.9 applications in total across the full sample (1978-2017). 55.8\%
} 
this in mind, for each applicant-year at, we construct the success rate over the prior three, five, and ten years. ${ }^{45}$

Second, we use information on the inventor team from the application. Note that unlike the applicants, where we restricted the sample to single-authored applicants from EPO member countries, we place no such restrictions on the inventor team. Indeed, following Drivas and Kaplanis (2020), we include dummy variables indicating if the inventor team crosses borders $($ Intl Team $)$ and whether there is an inventor in a different country than the applicant (Intl App-Inv $v_{a}$. Based on Drivas and Kaplanis (2020), we anticipate positive effects for these variables. Across the applications, there are a total of 2,118,753 inventors. On a given application, on average, there are 2.28 inventors. Overall, $40.9 \%$ of applications have a single inventor and another $26 \%$ have only two; $99.2 \%$ have eight or less. Similarly, $78.8 \%$ of inventors are listed on a single application, another $11.6 \%$ are listed on two, and 99.1\% are party to nine or fewer applications. For inventors listed on more than one application, the average success rate is $61.4 \%$. In contrast, the success rate of one-time inventors is only $57.5 \%$, i.e. those that are party to multiple applications are on average more successful in line with Drivas and Kaplanis (2020). ${ }^{46}$ We therefore control for the number of inventors on the application as in Guellec and van Pottelsburghe (2000). ${ }^{47}$ Furthermore, we construct two sets of variables for each application. First, we construct the average prior success rate for inventors on the application over the prior ten, five, and three years (where no applications in a given window is a zero success rate for the inventor). ${ }^{48}$ Second, it may

of the applicants have a single application and $92.4 \%$ have ten or less. Those with only one application during the full sample succeeded $45.9 \%$ of the time, those with two to ten applications succeeded $54.4 \%$ of the time, and those with more than ten applications were successful $61.3 \%$ of the time. Combined with the downward trend in applications and success discussed below, this indicates that the applications used in estimation are not out of line with the overall trends in the full sample.

${ }^{45}$ Of those submitting more than one application during the sample period, 40,422 (just over 54\%) file their first application during the estimation window of 2000-2012. Thus, given that our application data starts in 1978, we believe that we do a reasonable job of capturing an applicant's first application.

${ }^{46}$ When calculating these success rates for the applications used in estimation, the distribution was very similar.

${ }^{47}$ Guellec and van Pottelsburghe (2000) also control for the number of applicants which, given our sample choice, is always one in our data.

${ }^{48}$ Webster, et al. (2014) control for inventor experience, measured as the number of successful applications by a given inventor prior to the start of the estimation sample. 
be that the success of an application hinges on the research team leader who is guiding a group of inexperienced researchers without prior successes. As an alternative measure, for each application, we construct the prior success rates of the inventor in the team with the highest prior success rate. ${ }^{49}$

Third, we make use of the technology classes (Cooperative Patent Classification or CPC codes) listed on the applications. These CPCs are assigned by the EPO after receiving the application and indicate specific technology areas related to the application. Much like product or industry codes, CPCs can be grouped into broad or narrow categories with the narrowest in our data at the ten digit level. These CPCs are then used by the EPO to search for prior art and assess the novelty, and thus the patentability, of the application in question. It is no surprise that the success rate and the time it takes for successful decisions to be made can vary across CPCs. For each application, we add up the number of ten digit CPCs in a given three digit CPC. ${ }^{50}$ The average application has 4.82 ten digit CPCs which span an average of 1.61 three digit codes. ${ }^{51}$ From this, for each application $a$ and for each three-digit $\mathrm{CPC} c$, we construct a dummy variable equal to 1 if any of $a$ 's ten digit CPCs fall under $c .{ }^{52}$ We also keep track of the number of ten digit CPCs (Codes) each application covers. This mirrors Bösenberg and Egger (2017), Guellec and van Pottelsberghe (2000), and Lerner (1994) who use the number of technology codes as a proxy for patent quality. ${ }^{53}$

Fourth, we also know whether each of the applications submitted to the EPO were also submitted to the patent offices of the United States, Japan, China, and/or Korea. ${ }^{54}$

\footnotetext{
${ }^{49}$ Note that all of our prior success variables, as well as the number of applications by a given applicant, are constructed using the single-applicant data running from 1978-2017, not just that for our estimation window which, as described below, runs 2000-2012.

${ }^{50}$ In unreported results, we instead used the 647 different four digit categories. However, as one might imagine, this resulted in a very sparse set of data populated mainly by zeros. We therefore use the somewhat less sparse three digit classification where there are 128 different categories.

${ }^{51}$ Again, numbers are comparable for those applications used in estimation.

${ }^{52}$ In alternative results, we used the share of ten digit CPC codes in a given three digit code rather than dummies. Since for $58.2 \%$ of applications, all ten digit CPCs fall under a single three digit one, it is no surprise that these are quite similar and gave comparable results. We present the estimates using dummies here to ease interpretation of the CPC sub-sample results.

${ }^{53}$ Grimaldi and Cricelli (forthcoming) describe alternative approaches to measuring quality.

${ }^{54}$ In unreported results, we included a dummy equal to one if the EPO was the priority office for the application. This was insignificant and affected none of our other results. Although Guellec and van Pot-
} 
These, along with the EPO, constitute the five main patent offices globally. From this information, we construct Family Size which is the number of the five patent offices to which the application was submitted. ${ }^{55}$ In addition, we identify two sets of patents, triadic ones for which an application is made to at least three of these patent offices (of which the EPO is one) and pentadic applications which are submitted to all five. As each application is costly, it is our expectation that when the inventor believes the innovation is more valuable and/or has a greater chance of being granted a patent, they will tend to submit it to more patent offices. Thus, family size acts as a proxy for the inventor's private information on the innovation value. If innovation value is correlated with novelty, then family size should have a positive effect on success, a standard result in both the literature on taxes and patenting and that on the probability of success. Finally, as per Ernst, et al. (2014), Böhm, et al. (2015), and others we control for the number of forward and backwards citations (with forward citations for the first five years post-filing). More forward citations is presumed indicative of a more novel innovation and thus a higher probability of granting. More backwards citations, on the other hand, may indicate a large existing stock of prior art, indicating lower novelty and less success. Note that due to missing data in PATSTAT, we lose 1,634 applications when doing so.

For our 1,442,695 applications, Figure 1 plots the number of applications per year. As can be seen, there is a significant drop-off starting around 2015, a well-known pattern evidencing end-of-sample truncation in PATSTAT. Likewise, Figure 2, plots the success rate of applications filed in a given year. As one might expect, there is again a change towards the end of the sample, beginning around 2013. That this change in trend happens earlier than that found in the number of applications is not surprising since some applications filed in later years have yet to fully work their way through the examination process and are therefore not considered successful in our data. In our data, for applications submitted from 2000 to 2012

telsburghe (2000) find that success is higher at the priority office, their sample differs from ours in many dimensions including time coverage.

${ }^{55}$ Martinez (2010) discusses different approaches to defining family size. 
that were ultimately successful, the process took on average 1868.7 days, or approximately five years. Since our data ends in 2017 , this reinforces the idea that end-of-sample issues are contributing to the decline in success rates after 2012. With this in mind, we restrict the data used in estimation to include only those applications submitted up to and including $2012 .{ }^{56}$ One last feature of these two graphs is that the number of applications began to flat-line in 2008. At the same time, the average success rate reversed its prior downward trend, a reversal which lasted through 2011 although due to end of sample truncation it is unclear whether this reversal was temporary. ${ }^{57}$ If the financial crisis of 2008 reduced inventors' willingness to submit marginal patents during those years, these aggregate shifts may well be in line with the above discussion.

\subsection{Country Data}

In addition to controls derived from the patent applications, we include a number of countrylevel controls. First and foremost, we include four tax variables. First, we use the highest corporate income tax of country $i$ in year $t, C I T_{i t}$. Second, we include a dummy variable for whether $i$ has a patent box in place in year $t, B o x_{i t}$ as well as the difference between the

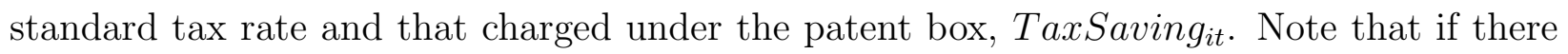
is no patent box, then TaxReduction Tit $=0 .{ }^{58}$ Further, we distinguish between patent boxes in two ways. First, boxes are categorized according to whether they are narrow, so that the preferential rate is available only to patents registered after the box is in effect, or broad, with the tax benefits extending to prexisting patents. ${ }^{59}$ Second, we identify which boxes

\footnotetext{
${ }^{56}$ In unreported results, we examined whether, for applications from 2000-2012 that were granted by the end of our data, there was a link between the introduction of a patent box and the length of time required for a decision. We found an effect indicating that, post-patent box, successful applications took six seconds longer to be approved, i.e. there was no appreciable difference in days to granting. Thus, we feel confident that the introduction of a patent box is not contributing to the end-of-sample truncation issue. These results are available on request.

${ }^{57}$ The overall decline in success rates is in line with the observations of Carley, et al. (2015) in US data.

${ }^{58}$ Evers, et al. (2015) provide a useful discussion of how patent boxes in Europe operate. Klemens (2016) also reviews patent boxes and provides a model suggesting that by allowing for separate taxes on mobile intellectual property and immobile fixed capital, patent boxes can increase tax competition.

${ }^{59}$ See Koethenbuerger, Liberini, and Stimmelmayr (2019) for discussion.
} 
have nexus requirements under which innovation must be done locally in order to qualify for the tax reduction. These tax data were obtained from Alstadsaeter, et al. (2018) and supplemented with data from the OECD and PWC Worldwide Tax Summaries as needed. ${ }^{60}$

Table 1 lists the EPO member countries using patent boxes, the dates of patent box effectiveness, and the tax saving. Note that excepting the French and Irish boxes, both of which began well before the start of the sample, the boxes became effective after 2000. Thus, following Alstadsaeter, et al. (2018) we restrict our attention to applications submitted from 2000 on. This, combined with the truncation in success rates observed in Figure 2, results in an estimation window from 2000 to 2012 for a total of 721,9825 applications. Fourth, we control for the b-index obtained from Bösenberg and Egger (2017). Although we direct the reader to their paper for details on the variable's construction, in short, it compares $R \& D$ tax incentives to the corporate income tax, with higher values translating to higher after-tax costs for R\&D.

Table 1 lists the number of applications by country during this period. ${ }^{61}$ It also lists the success rates by country during the estimation window. While for the sample as a whole, the success rate was $57.4 \%$, this varied across countries ranging from a Greek low of $40.4 \%$ to a Maltese high of $66.4 \%$ (although both make up very small shares of the sample). Of the countries with patent boxes active during the estimation period, only France had a success rate better than the EPO average (59.2\% versus the $57.4 \%$ mean). Digging deeper, Figure 3 plots the annual average success rates for the five countries which introduced patent boxes in the interior of our sample period (i.e. no closer than three years to the ends of the sample). As with Figure 2, this is for the applications filed in a given year, i.e. those filed in period 0 are those filed in the year the patent box takes effect. Excepting Spain, all experienced a rise in success rates in the patents filed in the years following patent box introduction.

Looking across the success rates in Table 1, there is no clear pattern for why some

\footnotetext{
${ }^{60}$ These can be found at https://stats.oecd.org/Index.aspx?DataSetCode=CTS_CIT and https://www.pwc.com/gx/en/services/tax/worldwide-tax-summaries.html respectively.

${ }^{61}$ Note that Estonia and Liechtenstein do not appear as they had no single-country, single-applicant applications during the sample period.
} 
countries have higher success rates. That said, larger, higher income countries submit more applications. Thus, in addition to the tax data, we include real GDP and GDP per capita for $i$ in $t$. Both are measured in logs and are obtained from the World Development Indicators. ${ }^{62}$ We also include R\&D spending relative to GDP, taken from the same source. Webster, et al. (2014) and others find that applications from countries with more R\&D spending in a given

field tend to have lower success rates, suggesting declining marginal returns to spending. ${ }^{63}$ While it would be desirable to have R\&D expenditures at the applicant level, doing so would force us to drop small inventors due to lack of data. ${ }^{64}$ Finally, we include a full complement of country and year dummies. In particular, if technological advantages are fairly stable over our thirteen year estimation window, we hope that the country dummies capture the impact of local advantages. ${ }^{65}$ This should also aid in filtering differences in industrial specialization. Likewise, inclusion of year dummies will help to filter out effects of common shocks such as the financial crisis. Table 3 lists the summary statistics for the observations used in our estimation window.

\subsection{Estimation Strategy}

Our goal is to estimate the probability of success of application $a$ from an applicant $i$ in country c published in year $t$ that contains CPC codes $k$. To this end, where Success $s_{\text {aictk }}$ is a dummy equal to one if the application is granted, we estimate the linear probability model:

$$
\text { Success }_{\text {aictp }}=\beta_{1} \text { Box }_{c t}+\beta_{2} X_{\text {aictp }}+\alpha_{i}+\alpha_{t}+\alpha_{c}+\varepsilon_{\text {aictk }}
$$

In this is our variable interest, $B o x_{c t}$, which indicates whether country $c$ has a patent

\footnotetext{
${ }^{62}$ These can be found at https://databank. worldbank.org/source/world-development-indicators. Note that as both are in logs this is equivalent to controlling for population and GDP per capita as in Gaessler, et al. (2019).

${ }^{63}$ This would be consistent with our assumptions on effort and success above.

${ }^{64}$ As found in Alstadsaeter, et al. (2018) and others, firms which spend more have more innovations. Falk (2007) estimates the aggregate number of patents in a country-year and investigates how this is influenced by where the total R\&D spending comes from with private sector expenditures having a larger effect than public money.

${ }^{65}$ See Webster, et al. (2014) for alternative approaches based on spending and exports.
} 
in place during the year application $a$ is submitted. In some specifications, this is instead altered to measure the tax savings offered by the patent box (where, in the absence of a box, the savings is zero). $X_{\text {aictp }}$ is a set of additional controls such as the number of offices the application is filed in, the prior success rate of the applicant, and the (non-patent box) corporate tax rate of country $c$ in $t$. The three $\alpha$ s represent a set of country, year, and CPC dummy variables. Finally, $\varepsilon_{\text {aictk }}$ is the robust error term which we cluster by country-year. Note that, our use of a linear probability model follows Drivas and Kaplanis (2020) and others with its main advantage being ease of interpreting the magnitude of coefficients. In robustness checks found below, we instead follow Guellec and van Pottelsburghe (2000) and employ a probit estimator. As shown there, the results are consistent across estimation approaches.

An important feature of our approach is one of timing since, in order to find an impact, the nature of applications would have to change primarily once the patent box is implemented. In broad boxes where the benefits apply to preexisting patents, the impact of the patent box may be felt before its actual introduction. ${ }^{66}$ Therefore, if we combine narrow and broad boxes, we would estimate a lower bound on the their effect. We explore the difference between narrow and broad boxes in the robustness checks where, as expected, the impacts are stronger for narrow boxes. ${ }^{67}$

\section{Results}

In this section, we build up to our preferred set of control variables before exploring subsets of the data, alternative estimators, and other robustness checks.

\footnotetext{
${ }^{66}$ As discussed by Ernst, et al. (2014), the introduction of a box is announced well ahead of its actual implementation.

${ }^{67}$ Alstadsaeter, et al. (2018) find that, for granted EPO patents, the number of registrations by a firm in a given EPO member country is greater when that member has a patent box.
} 


\subsection{Choosing the Control Variables}

Here, we describe how we arrive at our preferred specification. Table 4 begins by including only the patent box dummy and the corporate income tax (CIT) in addition to the country, year, and CPC dummy variables. As can be seen, the patent box has a positive effect on the predicted success rate where the presence of a patent box is associated with a 1.7 percentage point increase in the likelihood of the patent being granted. ${ }^{68}$ Given that the average success rate is $57.4 \%$, this 1.7 percentage point boost would translate into a $2.86 \%$ increase in the probability of success. ${ }^{69}$ This suggests that when a patent box is in effect in the year an application is filed, applicants increase the quality of the application with an economically meaningful effect. The CIT, on the other hand, has no impact on the success rate as predicted. Column 2 introduces the b-index. Doing so slightly increases the patent box effect. In addition, including this generates significant coefficients for the CIT and bindex, both of which predict less success. As shown momentarily, this second change is not robust to the inclusion of further country-level variables.

Column 3 introduces a number of application-level controls. As expected and consistent with the prior literature, applications with larger families, fewer technology codes, and more inventors have more success. Unlike Drivas and Kaplanis (2020), we find no impact from the international composition of the inventor team or the inventor-applicant combination (although we do below when introducing the prior success measures). We also find that an application from a frequent applicant (with a high number of total applications) is less likely to be successful. Our above model would predict this outcome if, for frequent applicants, more applications are of marginal novelty. Turning to the patent box variable, we again find a positive, significant effect. Column 4 expands our application controls to include the

\footnotetext{
${ }^{68}$ As the success outcome is either zero or one, a coefficient of .1 would mean a 10 percentage point increase in the expected probability of success. If the mean success rate is $50 \%$, that would then anticipate a $20 \%$ increase in the expected success rate. Throughout our discussion, we indicate whether we are talking about a percentage point change (10) or a percent change (20\%).

${ }^{69}$ That is, the 1.7 percentage point increase is added to a base of 57.4 percent, or an increase of $\frac{1.7}{57.4}=$ $2.86 \%$. Throughout, we endeavor to distingusih between the point estimate which is in percentage points and its economic magnitude which is in percent.
} 
number of forward and backwards citations. We only introduce citations in this column out of endogeneity concerns where granted patents may be cited more. That said, this has little effect on our other coefficients. Further, as expected we find that highly cited applications are more likely to be granted whereas those relying heavily on prior work are less so. ${ }^{70}$

Finally, Column 5 introduces three additional time-varying country controls. These suggest that applications from larger countries have less success with average income having no impact. Further, as in Webster, et al. (2014) we find that more aggregate R\&D spending lowers the average success rate, suggesting decreasing returns to spending. ${ }^{71}$ Although these additional variables do not have much effect on the application-level controls, they do impact the three tax variables. The patent box variable increases by a third in magnitude, suggesting a 3 percentage point higher success rate, and is now highly significant. In contrast, the CIT coefficient is now insignificant and the b-index is only marginally significant. Thus, when controlling in particular for R\&D spending, we find that while patent boxes tend to increase the average success of applications, as predicted the CIT and b-index have little effect.

In Table 5 we build upon this last specification by including prior success rates of the applicant and the inventors on a given application. Columns 1 through 3 include the applicant's prior success in the three, five, or ten years before submission of the application in question. In each instance (and across all Columns), greater past success is associated with a higher probability of the current application being granted. Using the estimate in Column 1, a 10 percentage point rise in success over the past three years would boost the probability of the current application being approved by 2.59 percentage points. In Columns 4 through 6, we also include the average prior success of the inventors listed on the application. As with the applicant, a higher average past success rate across the inventors increases the probability of the current application being granted with a 10 percentage point increase in

\footnotetext{
${ }^{70}$ Recall that the CPC dummies would control for the mean number of citations within a given technology class.

${ }^{71}$ Recalling that as both are in logs, including these is equivalent to including both GDP and population.
} 
past success leading to a 0.6 percentage point boost. Columns 7 through 9 repeat this but use the prior success rate of the most successful inventor on the team instead of the mean with the aim to capture the team leader's prior success. Again, more past success points to higher current success, although the point estimates are somewhat lower suggesting that teams may be more important than the leader alone. ${ }^{72}$

Turning to the other variables, including prior success has little impact on the patent box coefficient which, across specifications remains both significant and approximately the same in magnitude. Including prior success does, however, eliminate the scant significance of the b-index while the CIT again remains insignificant. The primary difference prior success causes is to the two dummies on the international composition of the team. We now tend to find that international inventor teams are significantly more successful, perhaps because these difficult working situations are only used when overseas inventors are especially important to a project. Conversely, if there is an inventor outside the applicant's country, the application is less like to succeed, suggesting potential home bias. Across the three, five, and ten year windows, the three year window gives a slightly higher adjusted R-squared. Therefore, we proceed by using the three year prior success rates of the applicant and mean inventor, simply noting that using other combinations yields very similar results which are available on request.

Interpreting our results in light of our model, the positive patent box coefficient suggests that on average the positive, intensive margin effect on effort dominates negative extensive margin effect driven by the submission of marginally novel applications. While our theory was agnostic as to the sign of the combination of these two, it did suggest that the net effect should be smaller for larger firms. With this in mind, we use total applications of an applicant as a proxy for size and explore this notion in Table 6. We begin by splitting the sample between those applicants who submit only once during the forty years of patent

\footnotetext{
${ }^{72}$ Alternatively, this may be due to the selection of the maximum. In a team led by a veteran researcher successful $80 \%$ of the time combined with a member who has only had one successful application in the past would find that the mean success rate is $90 \%$ whereas the maximum would be $100 \%$, i.e. our approach would give potentially misleading weight to the junior team member.
} 
data (Column 1) and those who submit multiple applications even if some of those fall outside of the estimation window (Column 2). In the first group, we now find no significant patent box effect (although we do for the other tax variables). ${ }^{73}$ Those applicants who make multiple applications during the sample, however, exhibit the pattern found in the full sample. In Columns 3 and 4, we break up those with multiple applications into a subset with two to ten applications (Column 3) and those with more than ten (Column 4). Again, we see a significant coefficient on the patent box variable only in the group of applicants submitting the most applications. While this might suggest that frequent applicants see the greatest patent box effect, it must be remembered that due to their frequent submissions, they make up the largest part of our data set. Single applicants only account for $11.5 \%$ of the sample; those with two to ten applications make up another $21.1 \%$. Thus, this difference in significance may be due to differences in sample size.

With this in mind, the last two columns try a different approach that uses the full sample and employs interaction terms. Column 5 interacts the patent box variable with dummies for applicants with two to ten applications and more than ten respectively. The coefficients indicate a positive effect from a patent box for infrequent applicants (with no difference between single applicants and those with two to ten applications) but a point estimate of only 0.007 for those with more than ten total applications, a net effect that is not statistically different from zero. This then supports the prediction that the impact of a patent box should be smaller for frequent innovators. Thus, the differences across Columns 1-4 may be driven by sample size. Column 6 instead uses an interaction between the patent box variable and the total applications by an applicant to allow for heterogenous patent box effects. Again, for a small innovator, we find a positive effect such that, for a single applicant the patent box is associated with a 4.4 percentage point increase in success. This effect falls, however, as the total number of applications grows. In particular, Column 6 estimates that the patent box would have a negative effect on the success rate of applicants with over 5,146 applications.

\footnotetext{
${ }^{73}$ Note that, by definition, these applicants have no prior successes.
} 
Thus, for the 66,908 applications from the eight largest applicants, the effect of the patent box is to lower the probability of success as would occur if many of these applications are for marginally novel innovations. Furthermore, we still find no role for the CIT or b-index. ${ }^{74}$ Column 6 of Table 6 then forms our preferred specification which we use as we explore subsamples of the data in our next set of estimations. ${ }^{75}$

\subsection{Subsamples}

Here, we explore a variety of subsamples of our data to test the robustness of our findings.

We begin with Table 7 where each column estimates our preferred specification but only using an application when at least one of its ten digit CPC codes falls under a given one digit code. $^{76}$ We do so based on the observation by Carley, et al. (2015) and others that success rates vary by technology classes. There are two reasons for doing so. First, as shown by Cohen, et al. (2000), the propensity to patent varies significantly across industries (and thus potentially across CPCs). Second, if the distribution of novelty varies across technologies, the relative magnitude of the extensive and intensive effects may vary across them as well. Although the average effect is filtered out by the CPC fixed effects, this alone does not permit heterogeneous responses to the tax variables across technologies. As can be seen, the coefficient pattern for the patent box is very consistent across technologies, although the significance varies. In particular, the pattern holds up well for CPCs B (Operations and Transport), C (Chemistry and Metallurgy), F (Mechanical Engineering), G(Physics), and Y(Emerging Technologies). The only CPC code where neither patent box variable is significant is D (Textiles) although it should be noted that this is also the technology with the lowest number of applications by some margin.

\footnotetext{
${ }^{74}$ In unreported results interacting total applications with these, we rarely found significant coefficients and, when we did, they varied in sign across different specifications. Thus, they point to no consistent effect from these measures. These additional results are available on request.

${ }^{75}$ Noting the skewed distribution in total applications, in unreported results we instead used the log of total applications rather than its level. Results were similar and are available on request.

${ }^{76}$ Note that as some applications cross one digit codes, the sum of observations across subsamples exceeds the total number of applications.
} 
In Figure 2, we recognized a decline in the success rate in 2013 arguably due to end of sample truncation matched with the time it takes for even the average successful application to be processed. Given that patent boxes were introduced over the years with only the Irish box being eliminated (before reintroduction outside of the estimation period), there is a concern that our patent box coefficient may be affected by end-of-sample truncation despite the inclusion of year dummies. With this in mind, Table 8 ends the estimation sample in 2011 (Column 2) and 2010 (Column 3). For easy comparison, the full estimation sample results are repeated in Column 1. As shown, this has little effect on the resulting estimates suggesting that they are not driven by truncation.

In Table 9 we omit various countries. First, as Ireland is the only country to remove a patent box during the period, Column 1 omits Ireland from the estimation. Column 2, on the other hand, reintroduces Ireland but omits the dozen countries with less than 1,000 applications during the sample period. These omissions have little impact on the results.

In Table 10 we allow the impact of the patent box to vary according to the number of patent offices to which a given application was made. We do so under the presumption that the number of offices to which an application is submitted is positively related to the firm's perception of the innovation's income potential. ${ }^{77}$ One might well expect that for a very valuable patent, more effort will be spent on the application and that, even if the underlying innovation is not particularly novel, that the firm would at least attempt to seek protect this valuable asset from competitors (two predictions our model generates). As such, if valuable applications will be completed with high effort and submitted either way, one might expect that their success rates are less influenced by a patent box. Thus, we anticipate that the coefficients of interactions between the patent box variables and family size will have the opposite signs of their non-interacted counterparts. As can be seen in Column 1, this is indeed the case where the effect of a patent box is 0.0637 for a single-office

\footnotetext{
${ }^{77}$ As discussed by Coelli, et al. (2016), the desire to export is a prime motivation for patenting overseas. Thus, in our data with patents coming from the EPO, applying elsewhere would be correlated with export potential and thus qualifying revenue.
} 
application but 0.0609 for one submitted to five offices, a difference of $4.4 \%$. In Column 2, we instead interact the patent box variables with a dummy for triadic patents and find a comparable effect. ${ }^{78}$ Finally, Column 3 again uses triadic interactions but also includes pentadic interactions where, for an application submitted to all five offices, both the triadic and pentadic dummies are one. While we do not find significance for the interaction between the patent box dummy and the pentadic dummy, the estimates again suggest that more offices imply a smaller patent box effect.

As described in Table 1 and in Figures 3, five countries introduced patent boxes in the middle of the estimation window. With this in mind, in Table 11, we rerun our estimation for just these countries. We do so for two reasons. First, these are the countries providing the variation in the patent box variable. ${ }^{79}$ Second, we do so out of concern for endogeneity. We believe that this is already a minor issue at worst for two reasons. First, it is unlikely that a government would introduce a patent box because of a single application. Thus, our use of disaggregated data provides one layer of protection from endogeneity. Second, as the dependent variable, whether an application is granted, is not realized for some time after the start date of the patent box, which provides a temporal argument against reverse causality. ${ }^{80}$ Nevertheless, it is possible that the introduction of a patent box is driven by some underlying factor specific to certain countries at certain points in time that can also be correlated with average success of applications coming from those countries at that time. By limiting our analysis and centering the data around the year of introduction, this helps to mitigate this final possibility. Thus, this treatment of the data provides a final check against endogeneity.

Column 1 uses the full estimation window where we find no significant impact of patent

\footnotetext{
${ }^{78}$ Recall that a triadic application is submitted to the EPO and at least two of the offices in the US, China, Korea, or Japan. In our data, 328,562 applications are triadic, just under half of the sample. Of those, 83,495 are pentadic and are submitted to all five.

${ }^{79}$ Ireland and Cyprus also have changes during the estimation window. We do not include Ireland because it removes its box rather than adding it. We do not include Cyprus as they do so only at the tail end of the estimation period. That said, including them in this exercise has little effect. Those alternative results are available on request.

${ }^{80}$ As noted above, we found no meaningful impact of patent boxes on the length of time required for granting.
} 
boxes. One possible reason for this is that, unlike in the full sample, this sub-sample has less variation in applicant size which makes it more difficult for the estimator to pull out, for example, the marginal effect of an increase in total applications. ${ }^{81}$ As an alternative, we return to the more coarse categorical interactions between the patent box and applicant size that was used in Table 6's Column 5. When doing so in Column 2, we find a coefficient pattern consistent with the comparable specification in Table 6 suggesting a positive (albeit insignificant) increase for smaller applicants and a significant drop in average success for larger applicants. In Column 3, we tighten the window to the year prior to application and the year of application. Doing so further strengthens the results which now mirror those in the main results. ${ }^{82}$ Finally, in Column 4, we only use the year prior to and the year immediately after introduction (omitting the year of introduction itself). We do so out of concern that the results in Column 3 may be driven by firms holding off slightly before submitting so that the patent box will apply. ${ }^{83}$ If they do so for highly novel innovations which may generate significant taxable income, this could generate the success rate changes. As can be seen, the results hold and the point estimates even become slightly larger. Thus, unless firms are willing to delay application and public use for two years because of the box (a costly and risky proposition for a valuable innovation), it does not seem that our results are driven by delays. Thus, restricting our attention to those countries introducing patent boxes and to the years surrounding the introduction again reinforces the notion that patent boxes may lead small applicants to invest more in the application procedure while inducing larger applicants to submit more marginally-novel applications.

\footnotetext{
${ }^{81}$ In this subsample, the mean and standard deviation of total applications are 3047.9 and 5857.4 . This is in comparison to 1922.4 and 5533.1 in the full sample.

${ }^{82}$ Note that in the narrow time frame here an in Column 4 , there is no within-country variation in the CIT or b-index and their coefficients cannot be estimated.

${ }^{83}$ That said, under EPO regulations, filing must generally occur within six months of public disclosure or use. See https://www.epo.org/law-practice/legal-texts/html/guidelines/e/g_v_2.htm for details.
} 


\subsection{Alternative Estimators}

Although our dependent variable takes on a value of zero or one, the linear probability model used above does not account for its discrete nature. With this in mind, in Table 12 we report the results using a probit estimator. We do so with caution, however, because as discussed by Greene (2004) when probit is combined with a large number of categorical variables, there is the potential for bias. That said, compared to the linear probability results repeated in Column 1, the probit results in Column 2 paint the same picture. We nevertheless use the linear probability in our presentation because of the ease it provides in interpreting the magnitude of the estimated effects. ${ }^{84}$

\subsection{Patent Box Characteristics}

Just as useful variation can be found by exploring application characteristics so too is it informative to exploit variation across patent boxes. Here we do so for three features of patent boxes: the tax breaks they offer, the patents they cover, and the requirements needed to avail of the box. None of these can be done using the patent box dummy variables above.

To begin with, Table 13 replaces the patent box dummy variable with the difference between the CIT rate and that afforded a granted patent under the patent box (which, in the absence of a box, is zero). In Column 1, we use the full sample and find results comparable to those when using the patent box dummy. Looking to the point estimate of the tax reduction (0.241) and noting that the average tax reduction is 19.1 percentage points, this would suggest that the introduction of the average patent box tax reduction would increase the probability of success by 4.6 percentage points, a figure quite close to the 4.4 percentage point boost found when using the dummy variable instead. In Column 2-4, we again restrict attention to the five countries introducing a patent box as in Table 11 and once again employ our category interactions. When doing so, we find a pattern very much as

\footnotetext{
${ }^{84}$ In results available on request, all presented results are available for the probit estimator. Here, we merely note that, as in Table 12 the results are in line with the linear probability ones.
} 
in Table 11 pointing to a positive effect of a patent box on the success small applicants but a smaller one for frequent applicants. In addition, we now find a significant effect for both tax reduction variables. Thus, while these estimates make it more challenging to describe the average effect of introducing a patent box since tax reductions vary, they paint a very similar picture.

In Table 14 we consider two additional aspects of patent boxes. First, as noted above narrow patent boxes provide tax breaks only for applications filed after the start of the box. In contrast, broad boxes provide tax relief to all active, qualifying patents. Since anticipation of a broad box may alter applicant behaviour prior to its introduction, we anticipate a muted effect in broad as compared to narrow boxes. ${ }^{85}$ With this in mind, in Column 1, we interact an indicator for a broad box with the patent box dummy. As can be seen, this has the opposite sign of the patent box dummy itself and predicts an increase of only 0.82 percentage points, an estimate that is indistinguishable from zero, i.e. the patent box effect is only for narrow boxes. In Column 2, we also interact the broad indicator with the interaction between the patent box dummy and total applications. Once again, we find opposing signs on the patent box dummy. That said, we now find a negative impact on larger innovators for both types of boxes. This does not, however, mean that broad patent boxes do not affect smaller innovators since those impacts may be occurring ahead of the box's implementation.

Finally, in Columns 3 and 4 we instead ask whether the role of patent boxes in application success depends on whether the box has a nexus requirement. This requirement specifies that, in order to qualify for the tax reductions within the box, a threshold amount of R\&D expenses must be performed in the box-using country. Such requirements are favored by those worried about patent boxes simply providing another avenue for income shifting (see, for example, Gaessler, et al., 2019). This may influence success if it encourages the use of

\footnotetext{
${ }^{85}$ See Alstadsaeter, et al. (2018) for discussion on this and other patent box conditions. Here, we point out that they find that box conditions can also affect the number of patents registered in an EPO country. Table 1 provides information on the conditions of various patent boxes in our sample.
} 
local resources, enhancing home bias in favor of the application. Alternatively, and perhaps more nefariously, nexus requirements may provide multinationals with an incentive to shift more novel (and more valuable) R\&D projects to nexus countries in order to minimize taxes. As this relocation would increase the average novelty in a country, and primarily by large innovators, this could boost average success. In Column 3, where we only interact the nexus requirement indicator with the patent box dummy, we find a sizable, significantly positive coefficient. This suggests that patent boxes that require local development have an impact nearly three times as large as those that do not. In Column 4, we also interact this with the total number of applications, again finding a significantly positive effect but only on the interaction with total applications, i.e. the boost in success is higher for frequent applicants. This then suggests that the differential impact of nexus boxes may be due to the relocation of the most novel (and lucrative) investment projects.

\subsection{Number of Applications}

Although it is not our main focus, the model predicts that the introduction of a patent box should increase the number of applications both as total R\&D rises and changes at the extensive margin lead to more submissions out of a given stock of innovations. With this in mind, we conclude with a short examination of the impact of a patent box on the number of applications submitted. We do so using the approach of Bösenberg and Egger (2017), who estimate the number of applications by country-year using a negative binomial estimator. Following their approach, we include a patent box dummy and the effective tax rate (Effective Tax Rate which equals the preferential rate if there is a patent box in effect or the CIT otherwise). ${ }^{86}$ They find negative coefficients on both, concluding that patent boxes increase applications by reducing the effective tax rate.

We take two approaches to the data: one at the country level (comparable to Bösenberg

\footnotetext{
${ }^{86}$ The negative binomial is also used by Alstadsaeter, et al. (2018) and Schwab and Totenhaupt (2019). Blundell, et al. (1995) and Falk (2007) use a dynamic count data estimator although neither controls for taxes.
} 
and Egger, 2017) and one at the applicant level (mimicking Alstadsaeter, et al., 2018). At the country level, we construct the total number of applications by country-year for the 2000-2012 estimation window. We do so for all applicants and then repeat the above stratification procedure and separately examine the country-year applications coming from single applicants, applicants with two to ten total applications, and applicants with more than ten total applications (where as above the total applications are for the full data set running from 1978 to 2017). ${ }^{87}$ At the applicant level, we form a balanced panel dataset of the number of applications per year, using the 1,100 applicants with at least 100 total applications. $^{88}$ We use only the largest applicants here because those studies operating at the firm level typically combine patent data with firm data, restricting attention to large innovators. This restriction thus helps with comparisons to the existing literature. Following the literature, we include GDP, GDP per capita, and R\&D spending relative to GDP, along with country and year dummies, as additional controls.

In Table 15, Column 1 reports country-year level estimates using all the applications. These results match those of Bösenberg and Egger (2017) and indicate that reductions in the effective tax rate from a patent box increase the number of applications. ${ }^{89}$ Since the average tax reduction from a patent box in our sample is 19.1 percentage points, the estimated coefficient on the effective tax rate suggests that a patent box would increase the number of applications by $0.15 \%$. We repeat the country-year level regressions in Columns 2 through 4 while stratifying across the three applicant groups. We find find little significant impact on small applicants but a strong effect on for applicants with more than ten total applications. For this group, the average tax change under a patent box results in a $0.4 \%$ increase in the number of applications in a year.

\footnotetext{
${ }^{87}$ In alternative estimates, we instead used the number of eventually granted applications per year and find similar results.

${ }^{88}$ Note that we do not control for total applications as an explanatory variable as it is clearly endogenous when the dependent variable is the number of applications in a year. This is not the case when the dependent variable is the outcome of a single application.

${ }^{89}$ It is worth noting that our estimated coefficient is quite close to theirs which was -0.610 . Unlike their results, however, we find no impact from the b-index.
} 
Column 5 presents applicant-year level data for those applicants with at least 100 total applications. The coefficient pattern remains the same as in the country-level approach, although results are generally less significant. This decrease in significance is potentially due to our lack of the firm-level controls which were used in Alstadsaeter et al. (2018) and Schwab and Totenhaupt (2019). ${ }^{90}$ Taken together, the results in Table 15 suggest that patent boxes generally increase the number of applications, especially for applicants who patent frequently.

\section{Conclusion}

It is undeniable that technological advancement is critical for continued growth. With this in mind, an increasing number of governments are exploring options of encouraging research and development including by offering income-based incentives such as patent boxes. Although an increasing body of work finds that these policies increase the number of patents, there is also concern that this is the result of reallocating completed patents and/or R\&D activity to low-tax locations. Further, there are concerns that the increase in patents may result from the patenting of mediocre innovations that would otherwise not be submitted for patenting.

With this in mind, we contribute in several ways. First, we present a model showing that a patent box can indeed lead to submission of marginal ideas. At the same time, it can encourage additional effort on the application of ideas that would have been submitted anyway, increasing the probability of success. That said, this latter effect will be more prominent for smaller firms. We then take this idea to applications to the EPO from 2000 to 2012. Controlling for a variety of factors, we find that on average a patent box is linked to an increase in average success rates. As predicted, however, the size of this effect is lower for frequent innovators and is negative for the largest innovators. As those innovators submit a significant proportion of total patents, this suggests that worries over excessive patenting of marginal innovations may be warranted. Furthermore, we find that the impact is essentially

\footnotetext{
${ }^{90}$ Unfortunately we were not able to achieve convergence when using applicant fixed effects.
} 
zero for broad patent boxes and markedly higher in those with nexus requirements (particularly for frequent innovators). This latter then again raises the specter of multinationals relocating successful innovation to low-tax jurisdictions following the implementation of a patent box.

\section{References}

[1] Agiakloglou, C., K. Drivas, and D. Karamanis. "Individual Inventors and Market Potentials: Evidence from US Patents." Science and Public Policy 43, no. 2(2016): 147-56.

[2] Alstadsaeter, A., S. Barrios, G. Nicodeme, A.M. Skonieczna, and A. Vezzani. (2018). Patent Boxes Design, Patents Location, and Local R\&D. Economic Policy, 33(93), 131177.

[3] Appelt, S., Bajgar, M., Criscuolo, C., and Galindo-Rueda, F. (2016). "R\&D Tax Incentives: Evidence on Design, Incidence, and Impacts." OECD Science, Technology, and Industry Policy Papers No. 32, OECD Publishing: Paris.

[4] Bacchiocchi, E. and Montobbio, F. (2010). International Knowledge Diffusion and Home-bias Effect: Do USPTO and EPO Patent Citations Tell the Same Story? The Scandinavian Journal of Economics, 112(3), 441-470.

[5] Balasubramanian, N. and J. Sivadasan (2011). 'What happens when firms patent? New evidence from U.S. economic census data', The Review of Economics and Statistics, 93, 126-46.

[6] Becker, J., C. Fuest, and N. Riedel (2012). Corporate Tax Effects on the Quality and Quantity of FDI. European Economic Review, 56(8), 1495-1511.

[7] Blundell, Richard, Griffith, Rachel, and Van Reenen, John. 1995. Dynamic count data models of technological innovation. The Economic Journal, 105(429), 333-344.

[8] Böhm, T., T. Karkinsky, B. Knoll and N. Riedel (2015), "Corporate Taxes and Strategic Patent Location within Multinational Firms", CESIfo Area Conference on Public Economics, April 2015.

[9] Bösenberg, S. and Egger, P. (2017). R\&D tax incentives and the emergence and trade of ideas. Economic Policy, 32(89), 39-80.

[10] Bradley, S., Dauchy, E. and Robinson, E. (2015) Cross-Country Evidence on the Preliminary Effects of Patent Box Regimes on Patent Activity and Ownership. National Tax Journal 64(4), 1047-1072. 
[11] Carley, M., D. Hegde, and A. Marco (2015). What is the Probability of Receiving a US Patent? Yale Journal of Law and Technology, 17(1), 203-223.

[12] Chen, S., De Simone, L., Hanlon, M. and Lester, R. (2019), The Effect of Innovation Box Regimes on Income Shifting and Real Activity, Working Paper No. 3452, Stanford.

[13] Ciaramella, L. (2017) Patent Boxes and the Relocation of Intellectual Property. Mimeo.

[14] Ciaramella, L., Martinez, C., and Meniere, Y. (2017) Tracking Patent Transfers in Different European Countries: Methods and a First Application to Medical Technologies. Scientometrics, 112, 817-850.

[15] Coelli, F., A. Moxnes, and K. Ulltveit-Moe. (2016). "Better, Faster, Stronger: Global Innovation and Trade Liberalization," NBER Working Paper 22647.

[16] Cohen, W.M., Nelson, R.R. and Walsh, J.P. (2000), "Protecting their intellectual assets: appropriability conditions and why US manufacturing firms patent (or Not)", Working Paper No. 7552, National Bureau of Economic Research, Cambridge, MA.

[17] de Rassenfosse, G., Jaffe, A. B., and Webster, E. (2016). Low-quality patents in the eye of the beholder: Evidence from multiple examiners (No. w22244). National Bureau of Economic Research.

[18] de Rassenfosse, G., Jensen, P. H., Julius, T. M., Palangkaraya, A., and Webster, E. (2018). Getting Patents: Does the Quality of Patent Attorney Matter?. Alfons and Webster, Elizabeth M., Getting Patents: Does the Quality of Patent Attorney Matter.

[19] de Rassenfosse, G., Raiteri, E., and Bekkers, R. (2017). Discrimination in the patent system: evidence from standard-essential patents. Mimeo.

[20] den Hertog, Pim, A. Vankan, B. Verspagen, P. Mohnen, L. Korlaar, B. Erven, M. Janssen and B. Mine (2016), Evaluatie innovatiebox 2010-2012. Publication number: 2015.034-1534

[21] Dischinger, M., and N. Riedel (2011), "Corporate taxes and the location of intangible assets within multinational firms". Journal of Public Economics, Vol. 95 (7-8), pp. 691707.

[22] Drivas, K. and Kaplanis, I. 2020. The Role of International Collaborations in Securing the Patent Grant. MPRA Paper No. 99520.

[23] Egger, P.H. and C. Keuschnigg (2015). 'Innovation, trade, and finance', American Economic Journal: Microeconomics, 7, 121-57.

[24] Ernst, C., K. Richter and N. Riedel (2014), "Corporate taxation and the quality of research and development", International Tax and Public Finance, Vol. 21, pp. 694719 .

[25] Ernst, C. and C. Spengel (2011), "Taxation, R\&D tax incentives and patent application in Europe", ZEW Discussion Papers, 11-024. 
[26] Evers, L., Miller, H., and Spengel, C. (2015) Intellectual Property Box Regimes: Effective Tax Rates and Tax Policy Considerations. International Tax and Public Finance, $22,502-530$.

[27] European Commission (2014) Patent Costs and Impact on Innovation. European Commission: Brussels.

[28] European Patent Office (2017) Unitary Patent Guide. EPO: Munich.

[29] Falk, M. (2007). 'What determines patents per capita in OECD countries?', Problems and Perspectives in Management, 5, 4-18.

[30] Frakes, M. D., and M. F. Wasserman. "Is the Time Allocated to Review Patent Applications Inducing Examiners to Grant Invalid Patents?: Evidence from Micro-Level Application Data." Review of Economics and Statistics (2016).

[31] Gaessler, F. (2016). Enforcing and trading patents. Evidence for Europe. Wiesbaden: Springer Gabler.

[32] Gaessler, F. Hall, B., and Harhoff, D. (2019) Should there be lower taxes on patent income? NBER Working Paper No. 24843.

[33] Greene, W. (2004). "The behaviour of the maximum likelihood estimator of limited dependent variable models in the presence of fixed effects," Economic Journal, 7(1), 98-119.

[34] Griffith, R., H. Miller, and M. O'Connell. (2014). Ownership of Intellectual Property and Corporate Taxation. Journal of Public Economics, 112, 12-23.

[35] Grimaldi, M. and Cricelli, L. (forthcoming): Indexes of patent value: a systematic literature review and classification, Knowledge Management Research \& Practice.

[36] Guellec, D., and B. van Pottelsberghe. 2000. "Applications, grants and the value of patent." Economics Letters 69:109-114.

[37] Hall, B.H., C. Helmers, M. Rogers and V. Sena (2014). 'The choice between formal and informal intellectual property: a review', Journal of Economic Literature, 52, 375-423.

[38] Hall, B.H. and Ziedonis, R.H. (2001), "The patent paradox revisited: an empirical study of patenting in the US semiconductor industry, 1979-1995", RAND Journal of Economics, Vol. 32 No. 1, pp. 101-128.

[39] Harhoff, D., K. Hoisl, B. Reichl, and B. van Pottelsberghe. "Patent Validation at the Country Level - The Role of Fees and Translation costs." Research Policy 38(2009): 1423-1437.

[40] IMF (2016), Fiscal Monitor - Acting Now, Acting Together: Fiscal Policies for Innovation and Growth (Chapter 2), International Monetary Fund, April 2016. 
[41] Kabore, F. and Park, W. (2019) Can patent family size and composition signal patent value? Applied Economics, 51(60), 6476-6496.

[42] Karkinsky, T. and N. Riedel (2012). Corporate Taxation and the Location of Patents within Multinational Firms. Journal of International Economics, 88(1), 176-185.

[43] Klemens, B. (2016). A Boxing Match: Can Intellectual Property Boxes Achieve Their Stated Goals? US Treasury Office of Tax Analysis.

[44] Koethenbuerger, M., Liberini, F., and Stimmelmayr, M. (2019) (Un)Intended Effects of Preferential Tax Regimes: The Case of European Patent Boxes. EconPol Working Paper No. 29/2019.

[45] Lei, Z., and Wright, B. D. (2017). Why weak patents? Testing the examiner ignorance hypothesis. Journal of Public Economics, 148, 43-56.

[46] Lemley, M. A., and B. Sampat. "Examiner characteristics and patent office outcomes." Review of Economics and Statistics 94, no. 3(2012): 817-827.

[47] Lerner, J. 1994. "The Importance of Patent Scope: An Empirical-Analysis." RAND Journal of Economics 25(2):319-333.

[48] Ludwig, C. (2018) Incentives for Multinational Corporations to Relocate Income. Mimeo.

[49] Martinez, C. (2010). Insights into Different Types of Patent Families. OECD: Paris.

[50] Mohnen, P., Vankan, A. and Verspagen, B. (2017) Evaluating the innovation box tax policy instrument in the Netherlands, 2007-13. Oxford Review of Economic Policy, 33(1), 141-156.

[51] Pezzoni, M., F. Lissoni, and G. Tarasconi (2014). How to Kill Inventors: Testing the Massacrator Algorithm for Inventor Disambiguation. Scientometrics, 101, 477-504.

[52] Peeters, C. and B. van Pottelsberghe (2006). 'Innovation strategy and the patenting behavior of firms', Journal of Evolutionary Economics, 16, 109-35.

[53] Reitzig, M. (2004). "Improving patent valuations for management purposes-validating new indicators by analyzing application rationales". Research Policy 33 (6-7), 939-57.

[54] Schwab, T. and Totenhaupt, M. (2019). Thinking Outside the Box: The Cross-Border Effect of Tax Cuts on R\&D. ZEW - Centre for European Economic Research Discussion Paper No. 16-073.

[55] Stiebale, J. 2016. Cross-border M\&As and innovative activity of acquiring and target firms. Journal of International Economics, 99, 1-15.

[56] Süzeroglu-Melchiors, S., Gassmann, O. and Palmie, M. (2017). "Friend or foe? The effects of patent attorney use on filing strategy vis-a-vis the effects of firm experience". Management Decision, 55(6) 1122-42. 
[57] van Zeebroeck, N., de la Potterie, B. V. P., and Guellec, D. (2009). Claiming more: the increased voluminosity of patent applications and its determinants. Research Policy, 38(6), 1006-1020.

[58] Webster, E., P. H. Jensen, and A. Palangkaraya. "Patent examination outcomes and the national treatment principle." Rand Journal of Economics 45, no. 2(2014): 449-469.

[59] Webster, E., Palangkaraya, A., and Jensen, P. H. (2007). Characteristics of international patent application outcomes. Economics Letters, 95(3), 362-368. 
Figure 1: Applications by Year, 1978-2017

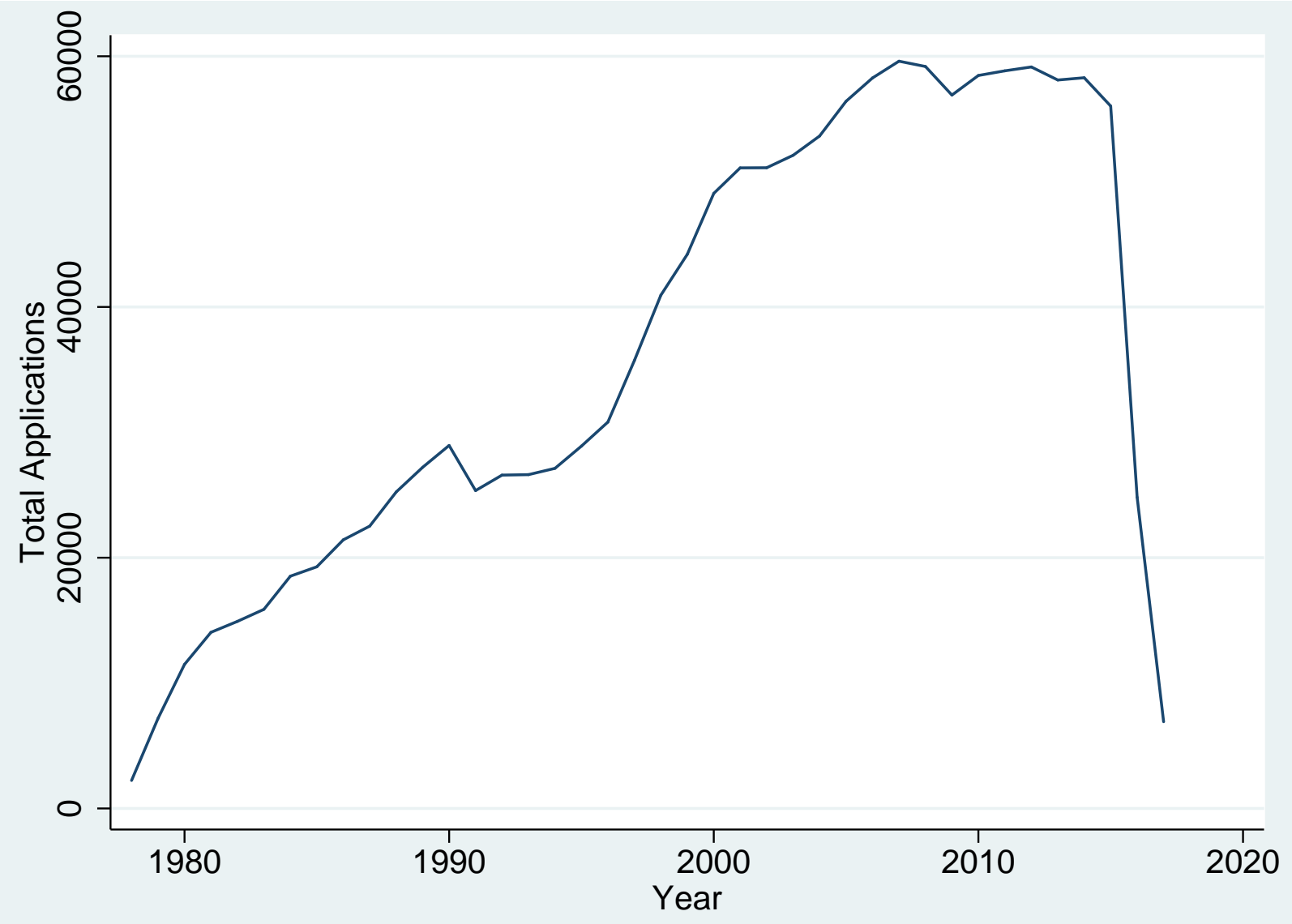


Figure 2: Success Rate by Year, 1978-2017

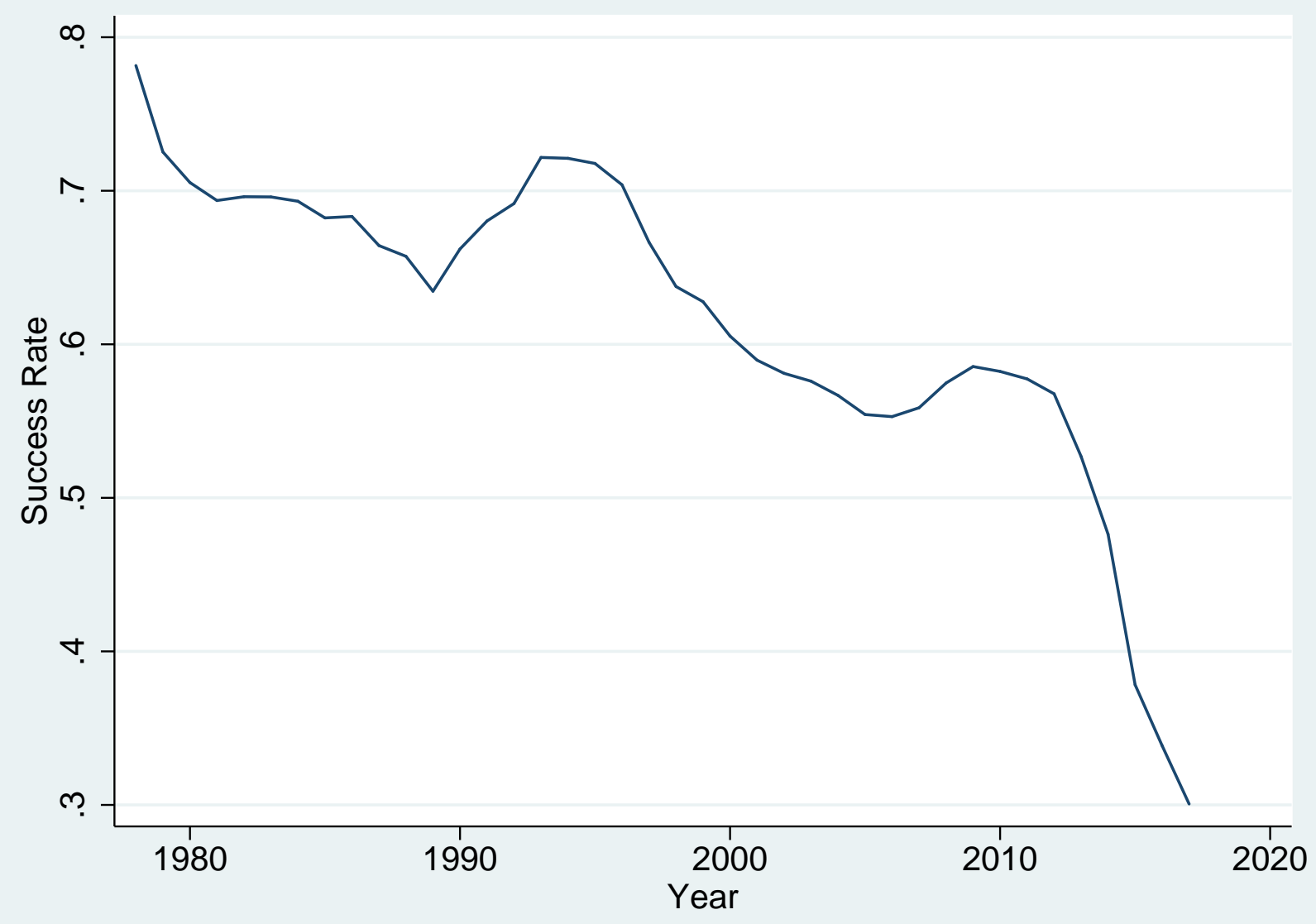


Figure 3: Success Rates Surrounding Patent Box Introduction

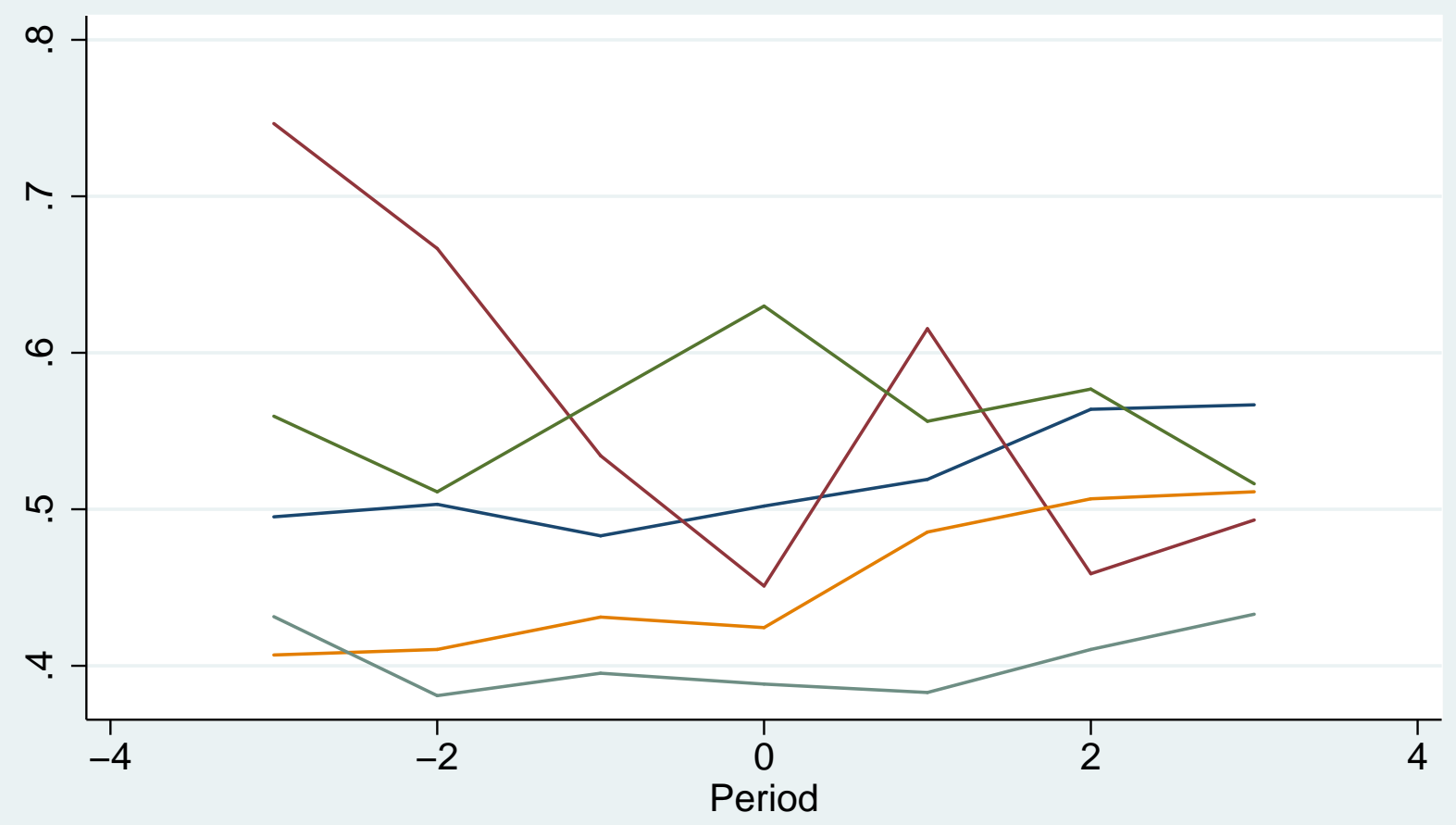

\begin{tabular}{|ll|}
\hline Belgium & Hungary \\
Luxembourg & Netherlands \\
Spain & \\
\hline
\end{tabular}


Table 1: Countries in the Sample

\begin{tabular}{|c|c|c|c|}
\hline Country & Number of Applications & Success Rate & Patent Box Years \\
\hline Austria & 15,662 & 62.6 & \\
\hline Belgium & 16,071 & 51.9 & $2007-{ }^{\dagger}$ \\
\hline Bulgaria & 124 & 51.6 & \\
\hline Croatia & 226 & 46.0 & \\
\hline Cyprus & 449 & 50.3 & $2012-^{*}$ \\
\hline Czech Republic & 1,136 & 52.3 & \\
\hline Denmark & 14,006 & 54.3 & \\
\hline Finland & 20,982 & 48.2 & \\
\hline France & 97,036 & 59.2 & 1971-* \\
\hline Germany & 278,869 & 62.1 & \\
\hline Greece & 697 & 40.5 & \\
\hline Hungary & 980 & 51.8 & $2003-^{*}$ \\
\hline Ireland & 4,716 & 51.8 & 1973-2010; 2016-*i \\
\hline Italy & 47,520 & 58.7 & $2017-$ \\
\hline Lithuania & 101 & 61.4 & $2018-$ \\
\hline Luxembourg & 3,610 & 57.3 & 2008 \\
\hline Malta & 280 & 66.4 & \\
\hline Netherlands & 49,642 & 45.7 & $2007-{ }^{\dagger}$ \\
\hline Norway & 5,104 & 54.5 & \\
\hline Poland & 1,544 & 47.9 & $2019-$ \\
\hline Portugal & 778 & 47.6 & \\
\hline Romania & 138 & 42.0 & \\
\hline Slovak Republic & 224 & 49.1 & $2018-$ \\
\hline Slovenia & 918 & 52.9 & \\
\hline Spain & 11,966 & 44.1 & $2008_{-*, \dagger}^{*}$ \\
\hline Sweden & 37,685 & 59.0 & \\
\hline Switzerland & 56,540 & 56.8 & $2011-^{*}$ \\
\hline Turkey & 2,284 & 59.6 & 2015- \\
\hline United Kingdom & 52,694 & 49.3 & \\
\hline
\end{tabular}

Notes: Ireland paused its patent box regime for five years following the financial crisis. The Swiss patent box only applies to the Nidwalden canton. ${ }^{*}$ indicates a broad patent box which applies to prexisting patents. $\dagger$ indicates a patent box with a nexus requirement. 
Table 2: CPC Codes

\begin{tabular}{lccc}
\hline CPC Code & Obs. & Success Rate & Days to Granting \\
\hline A: Human Necessities & & & \\
B: Operations and Transport & 141,880 & $56.7 \%$ & 1931.8 \\
C: Chemistry and Metallurgy & 193,358 & $65.0 .9 \%$ & 1694.2 \\
D: Textiles & 124,429 & $55.1 \%$ & 1969.8 \\
E: Fixed Constructions & 18,884 & $63.6 \%$ & 1774.9 \\
F: Mechanical Engineering & 42,303 & $58.1 \%$ & 1845.1 \\
G: Physics & 109,932 & $63.0 \%$ & 1770.3 \\
H: Electricity & 140,432 & $48.6 \%$ & 2022.1 \\
Y: Emerging Cross-Sectional Technologies & 152,337 & $53.8 \%$ & 2056.5 \\
\hline
\end{tabular}

Notes: Observations are the number of applications in the estimation window with a given CPC code listed. $66.7 \%$ of applications contain only one; $99.0 \%$ contain three or less. Thus, the sum of observations across rows exceeds the number of applications. 
Table 3: Summary Statistics

\begin{tabular}{lccccc}
\hline Variable & Obs & Mean & Std. Dev. & Min & Max \\
\hline Filing Date & & & & & \\
CIT & 721,982 & 2006.21 & 3.699376 & 2000 & 2012 \\
Patent Box & 721,982 & 0.3231647 & 0.0660521 & 0.1 & 0.5161155 \\
Patent Box Rate & 721,982 & 0.2054539 & 0.4040332 & 0 & 1 \\
Granted & 721,982 & 0.28395 & 0.1026276 & 0 & 0.5161155 \\
b-index & 721,982 & 0.5750517 & 0.4943355 & 0 & 1 \\
Codes & 721,982 & 0.9593423 & 0.1107948 & 0.5058044 & 1.042012 \\
Num. of Inv. & 721,982 & 5.11743 & 4.987319 & 1 & 331 \\
Intl Team & 721,982 & 2.391053 & 1.702221 & 1 & 99 \\
Intl App-Inv & 721,982 & 0.0860049 & 0.2803715 & 0 & 1 \\
For. Cites & 721,982 & 0.210418 & 0.4076058 & 0 & 1 \\
Back Cites & 721,982 & 2.509601 & 6.005957 & 0 & 585 \\
Total Apps & 721,982 & 5.042946 & 8.220629 & 0 & 1013 \\
Triadic & 721,982 & 1925.534 & 5538.687 & 1 & 27645 \\
Pentadic & 721,982 & 0.4534005 & 0.4978241 & 0 & 1 \\
GDP & 721,982 & 0.115032 & 0.3190607 & 0 & 1 \\
GDP per capita & 721,982 & 28.07875 & 0.9326102 & 22.69007 & 28.8964 \\
R\&D & 721,982 & 10.67471 & 0.2407937 & 8.282806 & 11.62597 \\
Days to Grant & 721,982 & 2.27825 & 0.6193777 & 0.2269 & 3.90785 \\
Prior Success (10 yrs) & 415,177 & 1867.626 & 922.0781 & 243 & 7075 \\
Prior Success (5 yrs) & 721,982 & 0.5542678 & 0.3766854 & 0 & 1 \\
Prior Success (3 yrs) & 721,982 & 0.5280779 & 0.3788735 & 0 & 1 \\
Mean Inv Success (10 yrs) & 721,982 & 0.4989291 & 0.3822787 & 0 & 1 \\
Mean Inv Success (5 yrs) & 721,982 & 0.1763771 & 0.2982134 & 0 & 1 \\
Mean Inv Success (3 yrs) & 721,982 & 0.1565929 & 0.2925466 & 0 & 1 \\
Max Inv Success (10 yrs) & 721,982 & 0.2853245 & 0.2830179 & 0 & 1 \\
Max Inv Success (5 yrs) & 721,982 & 0.2712225 & 0.4157727 & 0 & 1 \\
Max Inv Success (3 yrs) & 721,982 & 0.2495829 & 0.4068108 & 0 & 1 \\
\hline
\end{tabular}


Table 4: Baseline Estimates

\begin{tabular}{|c|c|c|c|c|c|}
\hline & (1) & $(2)$ & $(3)$ & (4) & $(5)$ \\
\hline Patent Box & $\begin{array}{l}0.0173^{* *} \\
(0.00871)\end{array}$ & $\begin{array}{l}0.0200^{* *} \\
(0.00819)\end{array}$ & $\begin{array}{l}0.0212^{* *} \\
(0.00905)\end{array}$ & $\begin{array}{l}0.0222^{* *} \\
(0.00884)\end{array}$ & $\begin{array}{c}0.0300^{* * *} \\
(0.00778)\end{array}$ \\
\hline CIT & $\begin{array}{r}-0.00577 \\
(0.0463)\end{array}$ & $\begin{array}{c}-0.0981^{*} \\
(0.0534)\end{array}$ & $\begin{array}{c}-0.121^{* *} \\
(0.0548)\end{array}$ & $\begin{array}{c}-0.108^{* *} \\
(0.0549)\end{array}$ & $\begin{array}{l}-0.0203 \\
(0.0635)\end{array}$ \\
\hline b-index & & $\begin{array}{c}-0.114^{* * *} \\
(0.0278)\end{array}$ & $\begin{array}{c}-0.113^{* * *} \\
(0.0286)\end{array}$ & $\begin{array}{c}-0.106^{* * *} \\
(0.0283)\end{array}$ & $\begin{array}{c}-0.0489^{*} \\
(0.0256)\end{array}$ \\
\hline Family Size & & & $\begin{array}{c}0.0487^{* * *} \\
(0.00172)\end{array}$ & $\begin{array}{c}0.0482^{* * *} \\
(0.00172)\end{array}$ & $\begin{array}{c}0.0483^{* * *} \\
(0.00172)\end{array}$ \\
\hline Codes & & & $\begin{array}{c}-0.000803^{* * *} \\
(0.000213)\end{array}$ & $\begin{array}{c}-0.000878^{* * *} \\
(0.000218)\end{array}$ & $\begin{array}{c}-0.000892^{* * *} \\
(0.000218)\end{array}$ \\
\hline Num. Inventors & & & $\begin{array}{c}0.00318^{* * *} \\
(0.000828)\end{array}$ & $\begin{array}{c}0.00277^{* * *} \\
(0.000821)\end{array}$ & $\begin{array}{c}0.00277^{* * *} \\
(0.000822)\end{array}$ \\
\hline Intl Team & & & $\begin{array}{l}-0.00260 \\
(0.00510)\end{array}$ & $\begin{array}{l}-0.00293 \\
(0.00511)\end{array}$ & $\begin{array}{l}-0.00310 \\
(0.00509)\end{array}$ \\
\hline Intl App-Inv & & & $\begin{array}{l}-0.00373 \\
(0.00594)\end{array}$ & $\begin{array}{c}-0.00330 \\
(0.00599)\end{array}$ & $\begin{array}{c}-0.00294 \\
(0.00599)\end{array}$ \\
\hline Forward Cites & & & & $\begin{array}{c}0.00264^{* * *} \\
(0.000162)\end{array}$ & $\begin{array}{c}0.00263 * * * \\
(0.000162)\end{array}$ \\
\hline Backward Cites & & & & $\begin{array}{c}-0.00162^{* * *} \\
(0.000367)\end{array}$ & $\begin{array}{c}-0.00160 * * * \\
(0.000365)\end{array}$ \\
\hline Total Apps. & & & $\begin{array}{c}-5.06 \mathrm{e}-06^{* * *} \\
(5.96 \mathrm{e}-07)\end{array}$ & $\begin{array}{c}-5.07 \mathrm{e}-06^{* * *} \\
(6.00 \mathrm{e}-07)\end{array}$ & $\begin{array}{c}-5.03 \mathrm{e}-06^{* * *} \\
(5.97 \mathrm{e}-07)\end{array}$ \\
\hline GDP & & & & & $\begin{array}{c}-0.445^{* * *} \\
(0.0776)\end{array}$ \\
\hline GDP per capita & & & & & $\begin{array}{c}0.0111 \\
(0.0746)\end{array}$ \\
\hline $\mathrm{R} \& \mathrm{D}$ & & & & & $\begin{array}{c}-0.0429 * * * \\
(0.0125)\end{array}$ \\
\hline Constant & $\begin{array}{c}0.544^{* * *} \\
(0.0496)\end{array}$ & $\begin{array}{c}0.687^{* * *} \\
(0.0616)\end{array}$ & $\begin{array}{c}0.627^{* * *} \\
(0.0639)\end{array}$ & $\begin{array}{c}0.618^{* * *} \\
(0.0637)\end{array}$ & $\begin{array}{c}13.19^{* * *} \\
(1.760)\end{array}$ \\
\hline Obs. & 721,982 & 721,982 & 721,982 & 721,982 & 721,982 \\
\hline Adj. $R^{2}$ & 0.041 & 0.041 & 0.057 & 0.059 & 0.059 \\
\hline
\end{tabular}




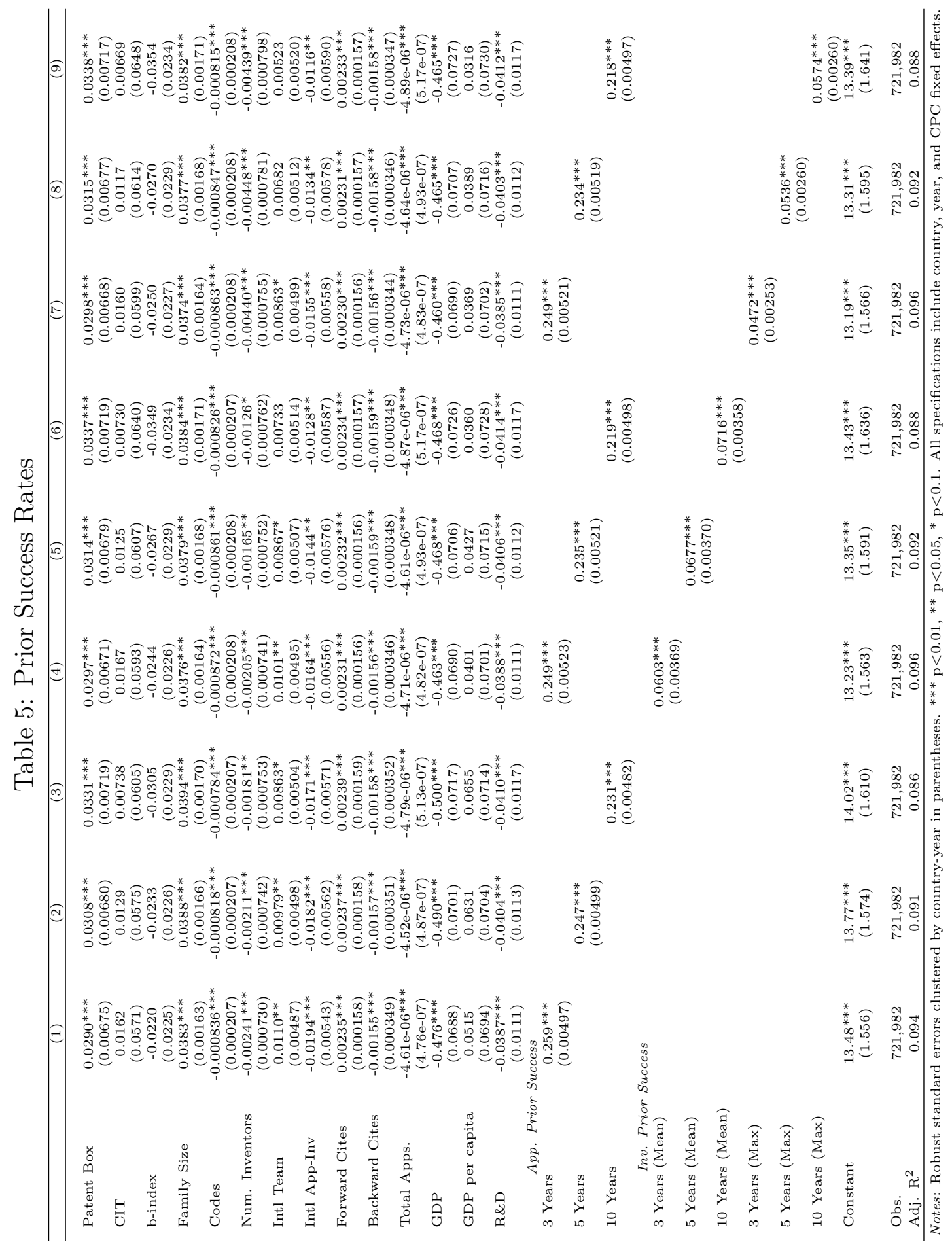




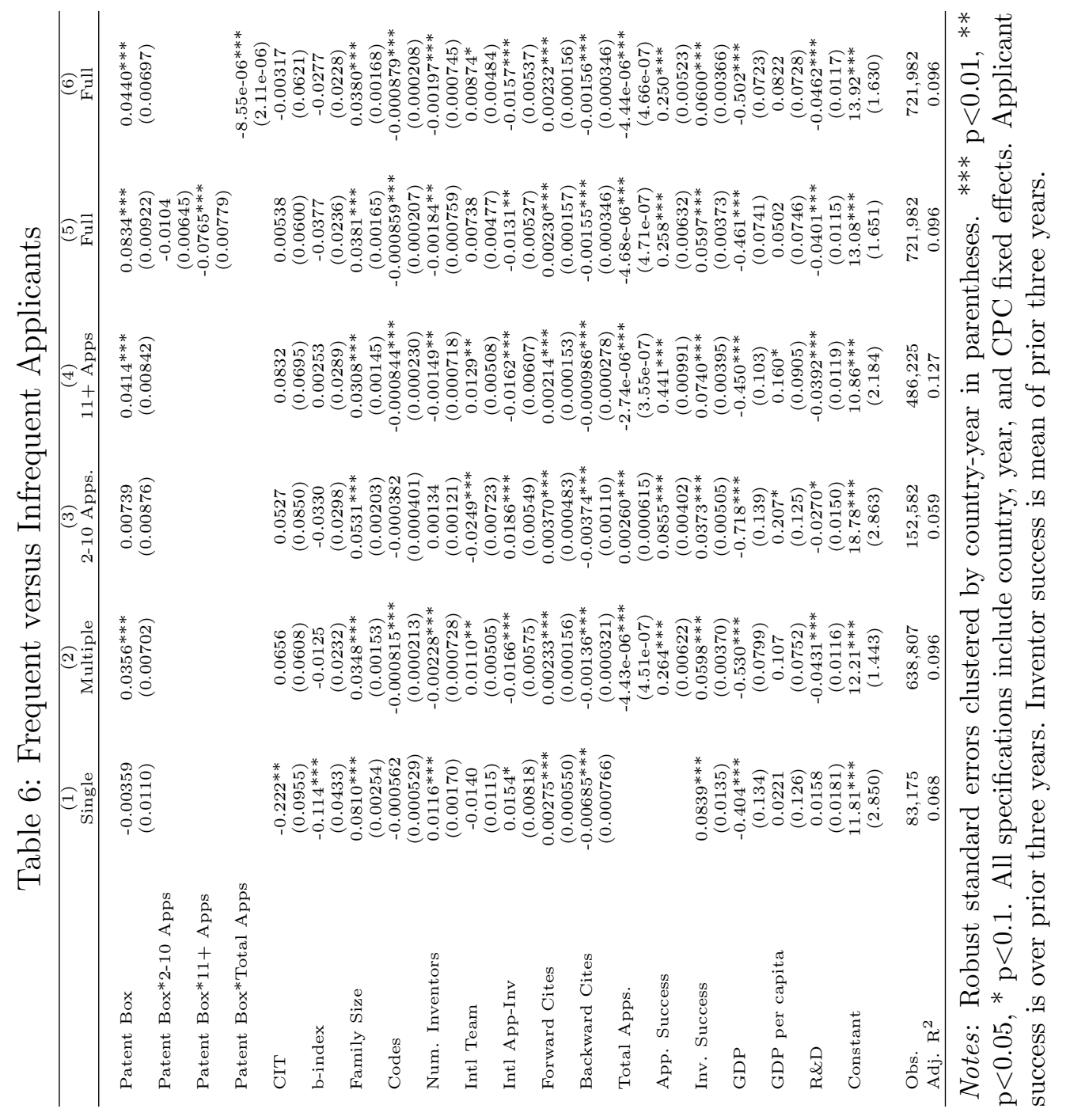




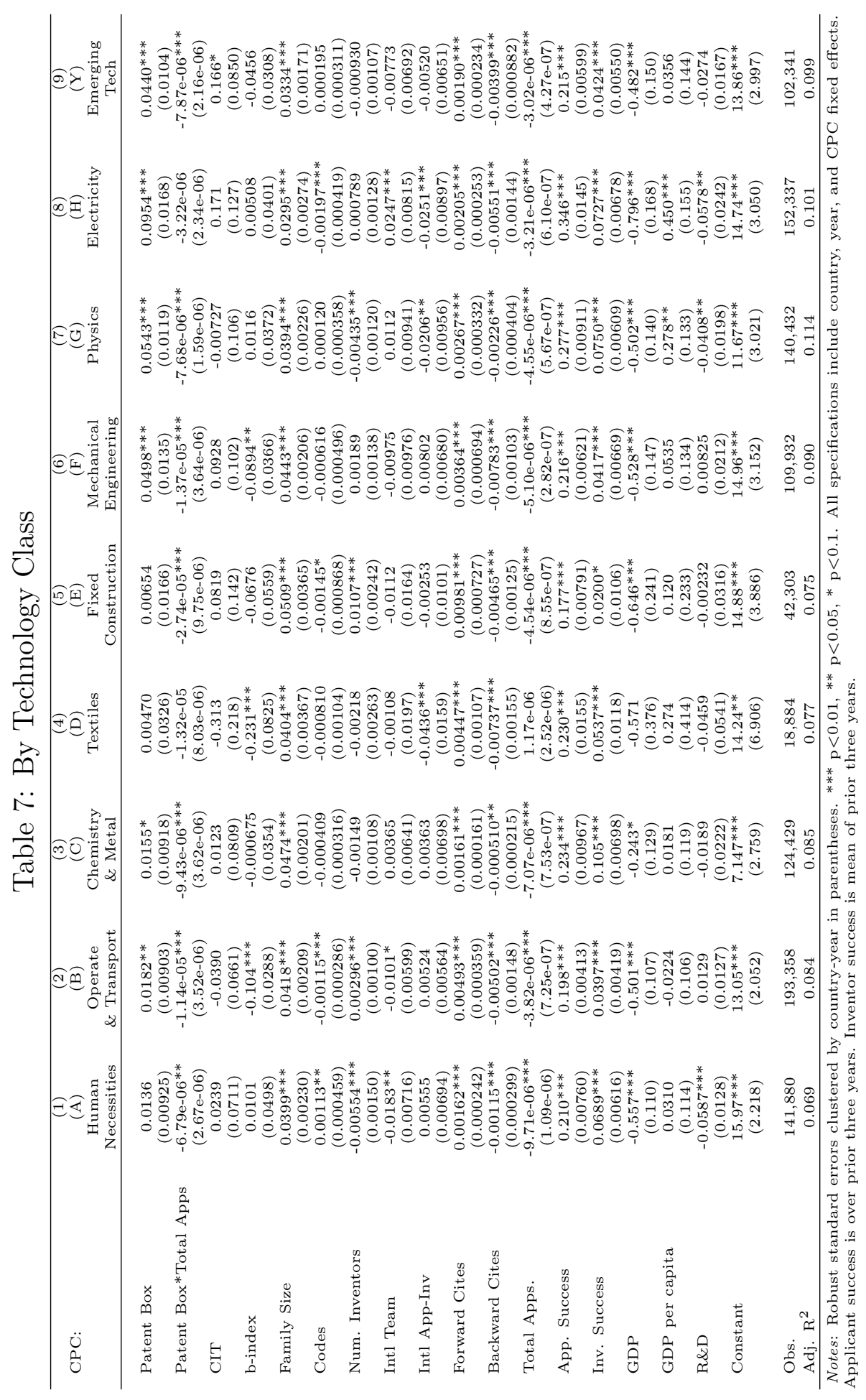


Table 8: Early Ending Dates

\begin{tabular}{|c|c|c|c|}
\hline Sample: & $\begin{array}{l}(1) \\
\text { Full } \\
\end{array}$ & $\begin{array}{c}(2) \\
\text { Ending } 2011 \\
\end{array}$ & $\begin{array}{c}(3) \\
\text { Ending } 2010 \\
\end{array}$ \\
\hline Patent Box & $\begin{array}{c}0.0440^{* * *} \\
(0.00697)\end{array}$ & $\begin{array}{c}0.0442^{* * *} \\
(0.00873)\end{array}$ & $\begin{array}{c}0.0452^{* * *} \\
(0.0105)\end{array}$ \\
\hline Patent Box*Total Apps & $\begin{array}{c}-8.55 \mathrm{e}-06^{* * *} \\
(2.11 \mathrm{e}-06)\end{array}$ & $\begin{array}{c}-7.67 \mathrm{e}-06 * * * \\
(1.97 \mathrm{e}-06)\end{array}$ & $\begin{array}{c}-6.85 \mathrm{e}-06 * * * \\
(1.97 \mathrm{e}-06)\end{array}$ \\
\hline CIT & $\begin{array}{r}-0.00317 \\
(0.0621)\end{array}$ & $\begin{array}{r}-0.00325 \\
(0.0652)\end{array}$ & $\begin{array}{c}0.00993 \\
(0.0587)\end{array}$ \\
\hline b-index & $\begin{array}{l}-0.0277 \\
(0.0228)\end{array}$ & $\begin{array}{l}-0.0235 \\
(0.0248)\end{array}$ & $\begin{array}{l}-0.0230 \\
(0.0264)\end{array}$ \\
\hline Family Size & $\begin{array}{c}0.0380^{* * *} \\
(0.00168)\end{array}$ & $\begin{array}{c}0.0384^{* * *} \\
(0.00176)\end{array}$ & $\begin{array}{c}0.0386^{* * *} \\
(0.00189)\end{array}$ \\
\hline Codes & $\begin{array}{c}-0.000879 * * * \\
(0.000208)\end{array}$ & $\begin{array}{c}-0.000671^{* * *} \\
(0.000205)\end{array}$ & $\begin{array}{c}-0.000461^{* *} \\
(0.000203)\end{array}$ \\
\hline Num. Inventors & $\begin{array}{c}-0.00197 * * * \\
(0.000745)\end{array}$ & $\begin{array}{c}-0.00188^{* *} \\
(0.000791)\end{array}$ & $\begin{array}{c}-0.00206^{* *} \\
(0.000827)\end{array}$ \\
\hline Intl Team & $\begin{array}{l}0.00874^{*} \\
(0.00484)\end{array}$ & $\begin{array}{l}0.00991^{*} \\
(0.00508)\end{array}$ & $\begin{array}{l}0.0118^{* *} \\
(0.00521)\end{array}$ \\
\hline Intl App-Inv & $\begin{array}{c}-0.0157^{* * *} \\
(0.00537)\end{array}$ & $\begin{array}{c}-0.0138^{* *} \\
(0.00557)\end{array}$ & $\begin{array}{c}-0.0133^{* *} \\
(0.00565)\end{array}$ \\
\hline Forward Cites & $\begin{array}{c}0.00232^{* * *} \\
(0.000156)\end{array}$ & $\begin{array}{c}0.00231^{* * *} \\
(0.000158)\end{array}$ & $\begin{array}{c}0.00227^{* * *} \\
(0.000158)\end{array}$ \\
\hline Backward Cites & $\begin{array}{c}-0.00156^{* * *} \\
(0.000346)\end{array}$ & $\begin{array}{c}-0.00201^{* * *} \\
(0.000398)\end{array}$ & $\begin{array}{c}-0.00282^{* * *} \\
(0.000323)\end{array}$ \\
\hline Total Apps. & $\begin{array}{c}-4.44 \mathrm{e}-06^{* * *} \\
(4.66 \mathrm{e}-07)\end{array}$ & $\begin{array}{c}-4.51 \mathrm{e}-06^{* * *} \\
(5.04 \mathrm{e}-07)\end{array}$ & $\begin{array}{c}-4.54 \mathrm{e}-06 * * * \\
(5.42 \mathrm{e}-07)\end{array}$ \\
\hline App. Success & $\begin{array}{l}0.250 * * * \\
(0.00523)\end{array}$ & $\begin{array}{l}0.252^{* * *} \\
(0.00543)\end{array}$ & $\begin{array}{l}0.254^{* * *} \\
(0.00568)\end{array}$ \\
\hline Inv. Success & $\begin{array}{c}0.0600 * * * \\
(0.00366)\end{array}$ & $\begin{array}{c}0.0586^{* * *} \\
(0.00376)\end{array}$ & $\begin{array}{c}0.0575^{* * *} \\
(0.00395)\end{array}$ \\
\hline GDP & $\begin{array}{c}-0.502^{* * *} \\
(0.0723)\end{array}$ & $\begin{array}{c}-0.491^{* * *} \\
(0.0839)\end{array}$ & $\begin{array}{c}-0.410 * * * \\
(0.0958)\end{array}$ \\
\hline GDP per capita & $\begin{array}{c}0.0822 \\
(0.0728)\end{array}$ & $\begin{array}{c}0.0635 \\
(0.0946)\end{array}$ & $\begin{array}{l}0.0393 \\
(0.132)\end{array}$ \\
\hline $\mathrm{R} \& \mathrm{D}$ & $\begin{array}{c}-0.0462^{* * *} \\
(0.0117)\end{array}$ & $\begin{array}{c}-0.0486^{* * *} \\
(0.0145)\end{array}$ & $\begin{array}{c}-0.0450 * * * \\
(0.0160)\end{array}$ \\
\hline Constant & $\begin{array}{c}13.92^{* * *} \\
(1.630)\end{array}$ & $\begin{array}{c}11.80 * * * \\
(1.513)\end{array}$ & $\begin{array}{c}10.08^{* * *} \\
(1.487)\end{array}$ \\
\hline $\begin{array}{l}\text { Obs. } \\
\text { Adj. } R^{2}\end{array}$ & $\begin{array}{c}721,982 \\
0.096\end{array}$ & $\begin{array}{c}663,213 \\
0.098\end{array}$ & $\begin{array}{c}604,730 \\
0.101\end{array}$ \\
\hline
\end{tabular}


Table 9: Omitting Countries

\begin{tabular}{|c|c|c|}
\hline Sample: & $\begin{array}{c}(1) \\
\text { No Ireland }\end{array}$ & $\begin{array}{c}(2) \\
\text { No }<1000 \text { Apps }\end{array}$ \\
\hline Patent Box & $\begin{array}{l}0.0464^{* * *} \\
(0.00749)\end{array}$ & $\begin{array}{c}0.0454^{* * *} \\
(0.00705)\end{array}$ \\
\hline Patent Box*Total Apps & $\begin{array}{c}-8.61 \mathrm{e}-06^{* * *} \\
(2.11 \mathrm{e}-06)\end{array}$ & $\begin{array}{c}-8.61 \mathrm{e}-06 * * * \\
(2.12 \mathrm{e}-06)\end{array}$ \\
\hline CIT & $\begin{array}{l}0.00751 \\
(0.0629)\end{array}$ & $\begin{array}{l}0.00349 \\
(0.0636)\end{array}$ \\
\hline b-index & $\begin{array}{l}-0.0290 \\
(0.0233)\end{array}$ & $\begin{array}{l}-0.0268 \\
(0.0231)\end{array}$ \\
\hline Family Size & $\begin{array}{c}0.0379 * * * \\
(0.00168)\end{array}$ & $\begin{array}{c}0.0379 * * * \\
(0.00168)\end{array}$ \\
\hline Codes & $\begin{array}{c}-0.000921^{* * *} \\
(0.000209)\end{array}$ & $\begin{array}{c}-0.000888^{* * *} \\
(0.000209)\end{array}$ \\
\hline Num. Inventors & $\begin{array}{c}-0.00194^{* *} \\
(0.000752)\end{array}$ & $\begin{array}{c}-0.00206^{* * *} \\
(0.000746)\end{array}$ \\
\hline Intl Team & $\begin{array}{l}0.00994^{* *} \\
(0.00487)\end{array}$ & $\begin{array}{c}0.00969^{* *} \\
(0.00485)\end{array}$ \\
\hline Intl App-Inv & $\begin{array}{c}-0.0171^{* * *} \\
(0.00539)\end{array}$ & $\begin{array}{c}-0.0164^{* * *} \\
(0.00538)\end{array}$ \\
\hline Forward Cites & $\begin{array}{c}0.00233^{* * *} \\
(0.000157)\end{array}$ & $\begin{array}{c}0.00232^{* * *} \\
(0.000157)\end{array}$ \\
\hline Backward Cites & $\begin{array}{c}-0.00156^{* * *} \\
(0.000347)\end{array}$ & $\begin{array}{c}-0.00156^{* * *} \\
(0.000346)\end{array}$ \\
\hline Total Apps. & $\begin{array}{c}-4.41 \mathrm{e}-06^{* * *} \\
(4.65 \mathrm{e}-07)\end{array}$ & $\begin{array}{c}-4.43 \mathrm{e}-06 * * * \\
(4.66 \mathrm{e}-07)\end{array}$ \\
\hline App. Success & $\begin{array}{l}0.250^{* * * *} \\
(0.00526)\end{array}$ & $\begin{array}{l}0.250 * * * \\
(0.00526)\end{array}$ \\
\hline Inv. Success & $\begin{array}{l}0.0600 * * * \\
(0.00368)\end{array}$ & $\begin{array}{l}0.0597 * * * \\
(0.00366)\end{array}$ \\
\hline GDP & $\begin{array}{c}-0.547^{* * *} \\
(0.0819)\end{array}$ & $\begin{array}{c}-0.520^{* * *} \\
(0.0752)\end{array}$ \\
\hline GDP per capita & $\begin{array}{c}0.123 \\
(0.0808)\end{array}$ & $\begin{array}{c}0.0963 \\
(0.0758)\end{array}$ \\
\hline $\mathrm{R} \& \mathrm{D}$ & $\begin{array}{c}-0.0480^{* * *} \\
(0.0119)\end{array}$ & $\begin{array}{c}-0.0481^{* * *} \\
(0.0120)\end{array}$ \\
\hline Constant & $\begin{array}{c}14.78 * * * \\
(1.805)\end{array}$ & $\begin{array}{c}12.14^{* * *} \\
(1.416)\end{array}$ \\
\hline $\begin{array}{l}\text { Obs. } \\
\text { Adj. } \mathrm{R}^{2}\end{array}$ & $\begin{array}{c}717,266 \\
0.096\end{array}$ & $\begin{array}{c}717,067 \\
0.096\end{array}$ \\
\hline
\end{tabular}

Notes: Robust standard errors clustered by country-year in parentheses. ${ }^{* * *} \mathrm{p}<0.01,{ }^{* *} \mathrm{p}<0.05,{ }^{*} \mathrm{p}<0.1$. All specifications include country, year, and CPC fixed effects. Applicant success is over prior three years. Inventor success is mean of prior thyge years. 
Table 10: Triadic and Pentadic Applications

\begin{tabular}{|c|c|c|c|}
\hline & $(1)$ & $(2)$ & $(3)$ \\
\hline Patent Box & $\begin{array}{c}0.0644 * * * \\
(0.0119)\end{array}$ & $\begin{array}{c}0.0526 * * * \\
(0.00779)\end{array}$ & $\begin{array}{c}0.0519 * * * \\
(0.00747)\end{array}$ \\
\hline Patent Box*Family Size & $\begin{array}{c}-0.00700^{*} \\
(0.00378)\end{array}$ & & \\
\hline Patent Box*Total Apps & $\begin{array}{c}-3.60 \mathrm{e}-05^{* * *} * \\
(5.37 \mathrm{e}-06)\end{array}$ & $\begin{array}{c}-3.35 \mathrm{e}-05^{* * *} * \\
(3.50 \mathrm{e}-06)\end{array}$ & $\begin{array}{c}-3.39 \mathrm{e}-05^{* * *} \\
(3.56 \mathrm{e}-06)\end{array}$ \\
\hline Patent Box*Total Apps*Family Size & $\begin{array}{c}7.08 \mathrm{e}-06 * * * \\
(1.21 \mathrm{e}-06)\end{array}$ & & \\
\hline Patent Box*Triadic & & $\begin{array}{l}-0.0149^{*} \\
(0.00865)\end{array}$ & $\begin{array}{l}-0.0140^{*} \\
(0.00811)\end{array}$ \\
\hline Patent Box*Total Apps*Triadic & & $\begin{array}{c}2.75 \mathrm{e}-05^{* * *} * \\
(3.45 \mathrm{e}-06)\end{array}$ & $\begin{array}{c}2.52 \mathrm{e}-05^{* * *} * \\
(3.56 \mathrm{e}-06)\end{array}$ \\
\hline Patent Box*Pentadic & & & $\begin{array}{l}-0.0142 \\
(0.0119)\end{array}$ \\
\hline Patent Box*Total Apps*Pentadic & & & $\begin{array}{c}8.51 \mathrm{e}-06^{* * *} \\
(1.51 \mathrm{e}-06)\end{array}$ \\
\hline CIT & $\begin{array}{c}-0.00400 \\
(0.0622)\end{array}$ & $\begin{array}{c}-0.00139 \\
(0.0618)\end{array}$ & $\begin{array}{l}0.00856 \\
(0.0602)\end{array}$ \\
\hline b-index & $\begin{array}{l}-0.0286 \\
(0.0226)\end{array}$ & $\begin{array}{l}-0.0282 \\
(0.0226)\end{array}$ & $\begin{array}{l}-0.0288 \\
(0.0227)\end{array}$ \\
\hline Family Size & $\begin{array}{c}0.0385 * * * \\
(0.00198)\end{array}$ & $\begin{array}{c}0.0380 * * * \\
(0.00185)\end{array}$ & $\begin{array}{c}0.0622 * * * \\
(0.00278)\end{array}$ \\
\hline Codes & $\begin{array}{c}-0.000857^{* * * *} \\
(0.000208)\end{array}$ & $\begin{array}{c}-0.000862^{* * * *} \\
(0.000207)\end{array}$ & $\begin{array}{c}-0.000848^{* * * *} \\
(0.000210)\end{array}$ \\
\hline Num. Inventors & $\begin{array}{c}-0.00195 * * * \\
(0.000743)\end{array}$ & $\begin{array}{c}-0.00193^{* *} \\
(0.000744)\end{array}$ & $\begin{array}{c}-0.00199 * * * \\
(0.000739)\end{array}$ \\
\hline Intl Team & $\begin{array}{c}0.00740 \\
(0.00471)\end{array}$ & $\begin{array}{c}0.00730 \\
(0.00472)\end{array}$ & $\begin{array}{c}0.00694 \\
(0.00451)\end{array}$ \\
\hline Intl App-Inv & $\begin{array}{c}-0.0139 * * * \\
(0.00516)\end{array}$ & $\begin{array}{c}-0.0138 * * * \\
(0.00517)\end{array}$ & $\begin{array}{c}-0.0128^{* * *} * \\
(0.00485)\end{array}$ \\
\hline Forward Cites & $\begin{array}{c}0.00231^{* * *} * \\
(0.000157)\end{array}$ & $\begin{array}{c}0.00232^{* * *} * \\
(0.000157)\end{array}$ & $\begin{array}{c}0.00239 * * * \\
(0.000161)\end{array}$ \\
\hline Backward Cites & $\begin{array}{c}-0.00156 * * * \\
(0.000346)\end{array}$ & $\begin{array}{c}-0.00155 * * * \\
(0.000345)\end{array}$ & $\begin{array}{c}-0.00152 * * * \\
(0.000338)\end{array}$ \\
\hline Total Apps. & $\begin{array}{c}-4.47 \mathrm{e}-06^{* * *} \\
(4.65 \mathrm{e}-07)\end{array}$ & $\begin{array}{c}-4.47 \mathrm{e}-06^{* * *} \\
(4.65 \mathrm{e}-07)\end{array}$ & $\begin{array}{c}-4.60 \mathrm{e}-06 * * * \\
(4.65 \mathrm{e}-07)\end{array}$ \\
\hline App. Success & $\begin{array}{l}0.250 * * * \\
(0.00530)\end{array}$ & $\begin{array}{l}0.250 * * * \\
(0.00530)\end{array}$ & $\begin{array}{l}0.248 * * * \\
(0.00528)\end{array}$ \\
\hline Inv. Success & $\begin{array}{c}0.0600 * * * \\
(0.00365)\end{array}$ & $\begin{array}{c}0.0601 * * * \\
(0.00365)\end{array}$ & $\begin{array}{c}0.0594 * * * \\
(0.00358)\end{array}$ \\
\hline GDP & $\begin{array}{c}-0.501 * * * \\
(0.0730)\end{array}$ & $\begin{array}{c}-0.501 * * * \\
(0.0728)\end{array}$ & $\begin{array}{c}-0.504^{* * * *} \\
(0.0707)\end{array}$ \\
\hline GDP per capita & $\begin{array}{c}0.0823 \\
(0.0734)\end{array}$ & $\begin{array}{c}0.0825 \\
(0.0733)\end{array}$ & $\begin{array}{c}0.0763 \\
(0.0713)\end{array}$ \\
\hline $\mathrm{R} \& \mathrm{D}$ & $\begin{array}{c}-0.0458^{* * *} * \\
(0.0117)\end{array}$ & $\begin{array}{c}-0.0455^{* * * *} \\
(0.0117)\end{array}$ & $\begin{array}{c}-0.0444^{* * *} * \\
(0.0118)\end{array}$ \\
\hline Constant & $\begin{array}{c}13.82^{* * *} \\
(1.634)\end{array}$ & $\begin{array}{c}13.88^{* * * *} \\
(1.640)\end{array}$ & $\begin{array}{c}14.00 * * * \\
(1.593)\end{array}$ \\
\hline Obs. & 721,982 & 721,982 & 721,982 \\
\hline Adj. $R^{2}$ & 0.096 & 0.096 & 0.098 \\
\hline
\end{tabular}

Notes: Robust standard errors clustered by country-year in parentheses. ${ }^{* * *} \mathrm{p}<0.01,{ }^{* *} \mathrm{p}<0.05,{ }^{*} \mathrm{p}<0.1$. All specifications include country, year, and CPC fixed effects. Applicant success is over prior three years. Inventor success is mean of prior three years. 
Table 11: Countries Introducing a Patent Box

\begin{tabular}{|c|c|c|c|c|}
\hline Years: & $\begin{array}{l}(1) \\
\text { All }\end{array}$ & $\begin{array}{l}(2) \\
\text { All }\end{array}$ & $\begin{array}{c}(3) \\
-1 \text { to } 0\end{array}$ & $\begin{array}{c}(4) \\
-1 \text { and }+1\end{array}$ \\
\hline Patent Box & $\begin{array}{l}-0.0220 \\
(0.0175)\end{array}$ & $\begin{array}{c}0.0279 \\
(0.0257)\end{array}$ & $\begin{array}{c}0.106^{* * *} \\
(0.0267)\end{array}$ & $\begin{array}{c}0.168^{* * *} \\
(0.0457)\end{array}$ \\
\hline Patent Box*Total Apps & $\begin{array}{c}2.17 \mathrm{e}-06 \\
(2.70 \mathrm{e}-06)\end{array}$ & & & \\
\hline Patent Box*2-10 Apps & & $\begin{array}{l}-0.0232 \\
(0.0144)\end{array}$ & $\begin{array}{l}-0.0194 \\
(0.0345)\end{array}$ & $\begin{array}{c}-0.00960 \\
(0.0414)\end{array}$ \\
\hline Patent Box*11+ Apps & & $\begin{array}{c}-0.0798 * * * \\
(0.0183)\end{array}$ & $\begin{array}{c}-0.0789^{* *} \\
(0.0295)\end{array}$ & $\begin{array}{c}-0.0958^{* *} \\
(0.0367)\end{array}$ \\
\hline CIT & $\begin{array}{c}0.222 \\
(0.265)\end{array}$ & $\begin{array}{c}0.201 \\
(0.277)\end{array}$ & & \\
\hline b-index & $\begin{array}{c}0.0366 \\
(0.122)\end{array}$ & $\begin{array}{l}0.0211 \\
(0.132)\end{array}$ & & \\
\hline Family Size & $\begin{array}{c}0.0463^{* * *} \\
(0.00502)\end{array}$ & $\begin{array}{c}0.0471^{* * *} \\
(0.00513)\end{array}$ & $\begin{array}{c}0.0539 * * * \\
(0.00365)\end{array}$ & $\begin{array}{c}0.0500 * * * \\
(0.00315)\end{array}$ \\
\hline Codes & $\begin{array}{c}-0.00176^{* * *} \\
(0.000493)\end{array}$ & $\begin{array}{c}-0.00175^{* * *} \\
(0.000482)\end{array}$ & $\begin{array}{l}-0.000615 \\
(0.00104)\end{array}$ & $\begin{array}{c}-0.00277^{*} \\
(0.00128)\end{array}$ \\
\hline Num. Inventors & $\begin{array}{c}0.00498 * * * \\
(0.00162)\end{array}$ & $\begin{array}{c}0.00586^{* * *} \\
(0.00153)\end{array}$ & $\begin{array}{l}0.00646^{* *} \\
(0.00278)\end{array}$ & $\begin{array}{c}0.00535 \\
(0.00333)\end{array}$ \\
\hline Intl Team & $\begin{array}{c}-0.0311^{* *} \\
(0.0119)\end{array}$ & $\begin{array}{c}-0.0333^{* * *} \\
(0.0123)\end{array}$ & $\begin{array}{l}0.00829 \\
(0.0126)\end{array}$ & $\begin{array}{c}0.0168 \\
(0.0166)\end{array}$ \\
\hline Intl App-Inv & $\begin{array}{c}0.0308^{* * *} \\
(0.00958)\end{array}$ & $\begin{array}{c}0.0338^{* * *} \\
(0.00969)\end{array}$ & $\begin{array}{r}-0.00313 \\
(0.0182)\end{array}$ & $\begin{array}{c}-0.0223 \\
(0.0184)\end{array}$ \\
\hline Forward Cites & $\begin{array}{c}0.00292^{* * *} \\
(0.000379)\end{array}$ & $\begin{array}{c}0.00291^{* * *} \\
(0.000376)\end{array}$ & $\begin{array}{c}0.00266 * * * \\
(0.000529)\end{array}$ & $\begin{array}{c}0.00322^{* * *} \\
(0.000826)\end{array}$ \\
\hline Backward Cites & $\begin{array}{c}-0.00208 * * * \\
(0.000673)\end{array}$ & $\begin{array}{c}-0.00207^{* * *} \\
(0.000668)\end{array}$ & $\begin{array}{l}-0.00248 \\
(0.00167)\end{array}$ & $\begin{array}{l}-0.00123 \\
(0.00145)\end{array}$ \\
\hline Total Apps. & $\begin{array}{c}-1.50 \mathrm{e}-05^{* * *} \\
(3.02 \mathrm{e}-06)\end{array}$ & $\begin{array}{c}-1.38 \mathrm{e}-05^{* * *} \\
(2.48 \mathrm{e}-06)\end{array}$ & $\begin{array}{c}-1.29 \mathrm{e}-05^{* * *} \\
(1.42 \mathrm{e}-06)\end{array}$ & $\begin{array}{c}-1.02 \mathrm{e}-05^{* *} \\
(3.93 \mathrm{e}-06)\end{array}$ \\
\hline App. Success & $\begin{array}{c}0.250^{* * *} \\
(0.0221)\end{array}$ & $\begin{array}{c}0.268^{* * *} \\
(0.0238)\end{array}$ & $\begin{array}{c}0.294^{* * *} \\
(0.0326)\end{array}$ & $\begin{array}{c}0.293^{* * *} \\
(0.0378)\end{array}$ \\
\hline Inv. Success & $\begin{array}{c}0.0991^{* * *} \\
(0.0135)\end{array}$ & $\begin{array}{c}0.0992^{* * *} \\
(0.0141)\end{array}$ & $\begin{array}{c}0.0833^{* * *} \\
(0.0238)\end{array}$ & $\begin{array}{c}0.0614^{* *} \\
(0.0268)\end{array}$ \\
\hline GDP & $\begin{array}{c}-0.681^{* * *} \\
(0.249)\end{array}$ & $\begin{array}{c}-0.847^{* * *} \\
(0.246)\end{array}$ & $\begin{array}{c}-1.122^{* * *} \\
(0.0822)\end{array}$ & $\begin{array}{c}-0.266^{* *} \\
(0.116)\end{array}$ \\
\hline GDP per capita & $\begin{array}{c}0.469 \\
(0.384)\end{array}$ & $\begin{array}{l}0.761^{*} \\
(0.423)\end{array}$ & $\begin{array}{c}-3.026^{* * *} \\
(0.215)\end{array}$ & $\begin{array}{c}-0.611^{*} \\
(0.300)\end{array}$ \\
\hline$R \& D$ & $\begin{array}{c}-0.106^{* * *} \\
(0.0309)\end{array}$ & $\begin{array}{c}-0.141^{* * *} \\
(0.0327)\end{array}$ & $\begin{array}{c}0.365^{* * *} \\
(0.0512)\end{array}$ & $\begin{array}{l}-0.0578 \\
(0.0666)\end{array}$ \\
\hline Constant & $\begin{array}{c}14.46^{* * *} \\
(4.624)\end{array}$ & $\begin{array}{c}16.12^{* * *} \\
(4.382)\end{array}$ & $\begin{array}{c}62.46^{* * *} \\
(4.557)\end{array}$ & $\begin{array}{l}12.86^{*} \\
(5.803)\end{array}$ \\
\hline Obs. & 82,269 & 82,269 & 14,071 & 13,508 \\
\hline Adj. $R^{2}$ & 0.115 & 0.117 & 0.128 & 0.113 \\
\hline
\end{tabular}

Notes: Robust standard errors clustered by country-year in parentheses. ${ }^{* * *} \mathrm{p}<0.01,{ }^{* *} \mathrm{p}<0.05$, $* \mathrm{p}<0.1$. All specifications include country, year, and CPC fixed effects. Applicant success is over prior three years. Inventor success is mean of prior three years. Year 0 is the year of patent box introduction. 
Table 12: Linear Probability versus Probit

\begin{tabular}{|c|c|c|}
\hline Estimator: & $\begin{array}{c}(1) \\
\text { Linear Probability } \\
\end{array}$ & $\begin{array}{c}(2) \\
\text { Probit } \\
\end{array}$ \\
\hline Patent Box & $\begin{array}{c}0.0440^{* * *} \\
(0.00697)\end{array}$ & $\begin{array}{c}0.120^{* * *} \\
(0.0189)\end{array}$ \\
\hline Patent Box*Total Apps & $\begin{array}{c}-8.55 \mathrm{e}-06^{* * *} \\
(2.11 \mathrm{e}-06)\end{array}$ & $\begin{array}{c}-2.35 \mathrm{e}-05^{* * * *} \\
(6.18 \mathrm{e}-06)\end{array}$ \\
\hline CIT & $\begin{array}{r}-0.00317 \\
(0.0621)\end{array}$ & $\begin{array}{c}-0.00896 \\
(0.173)\end{array}$ \\
\hline b-index & $\begin{array}{l}-0.0277 \\
(0.0228)\end{array}$ & $\begin{array}{l}-0.0775 \\
(0.0626)\end{array}$ \\
\hline Family Size & $\begin{array}{c}0.0380^{* * *} \\
(0.00168)\end{array}$ & $\begin{array}{l}0.105^{* * *} \\
(0.00459)\end{array}$ \\
\hline Codes & $\begin{array}{c}-0.000879^{* * *} \\
(0.000208)\end{array}$ & $\begin{array}{c}-0.00252^{* * * *} \\
(0.000575)\end{array}$ \\
\hline Num. Inventors & $\begin{array}{c}-0.00197^{* * *} \\
(0.000745)\end{array}$ & $\begin{array}{c}-0.00576^{* * * *} \\
(0.00209)\end{array}$ \\
\hline Intl Team & $\begin{array}{l}0.00874^{*} \\
(0.00484)\end{array}$ & $\begin{array}{l}0.0232^{*} \\
(0.0131)\end{array}$ \\
\hline Intl App-Inv & $\begin{array}{c}-0.0157^{* * *} \\
(0.00537)\end{array}$ & $\begin{array}{c}-0.0445^{* * * *} \\
(0.0146)\end{array}$ \\
\hline Forward Cites & $\begin{array}{c}0.00232 * * * \\
(0.000156)\end{array}$ & $\begin{array}{c}0.00679 * * * \\
(0.000534)\end{array}$ \\
\hline Backward Cites & $\begin{array}{c}-0.00156^{* * *} \\
(0.000346)\end{array}$ & $\begin{array}{c}-0.00389^{* * * *} \\
(0.000912)\end{array}$ \\
\hline Total Apps. & $\begin{array}{c}-4.44 \mathrm{e}-06^{* * *} \\
(4.66 \mathrm{e}-07)\end{array}$ & $\begin{array}{c}-1.22 \mathrm{e}-05^{* * *} \\
(1.22 \mathrm{e}-06)\end{array}$ \\
\hline App. Success & $\begin{array}{l}0.250^{* * *} \\
(0.00523)\end{array}$ & $\begin{array}{c}0.675^{* * *} \\
(0.0146)\end{array}$ \\
\hline Inv. Success & $\begin{array}{c}0.0600^{* * *} \\
(0.00366)\end{array}$ & $\begin{array}{l}0.173^{* * * *} \\
(0.0103)\end{array}$ \\
\hline GDP & $\begin{array}{c}-0.502^{* * *} \\
(0.0723)\end{array}$ & $\begin{array}{c}-1.358^{* * * *} \\
(0.198)\end{array}$ \\
\hline GDP per capita & $\begin{array}{c}0.0822 \\
(0.0728)\end{array}$ & $\begin{array}{c}0.197 \\
(0.200)\end{array}$ \\
\hline$R \& D$ & $\begin{array}{c}-0.0462^{* * *} \\
(0.0117)\end{array}$ & $\begin{array}{c}-0.124^{* * *} \\
(0.0324)\end{array}$ \\
\hline Constant & $\begin{array}{c}13.92^{* * *} \\
(1.630)\end{array}$ & $\begin{array}{c}35.23^{* * *} \\
(4.368)\end{array}$ \\
\hline $\begin{array}{l}\text { Obs. } \\
\text { Adj. } R^{2}\end{array}$ & $\begin{array}{c}721,982 \\
0.096\end{array}$ & 721,982 \\
\hline
\end{tabular}

Notes: Robust standard errors clustered by country-year in parentheses. ${ }^{* * *} \mathrm{p}<0.01,{ }^{* *} \mathrm{p}<0.05,{ }^{*} \mathrm{p}<0.1$. All specifications include country, year, and CPC fixed effects. Applicant success is over prior three years. Inventor success is mean of prior three years. 56 
Table 13: Tax Reductions in the Patent Box

\begin{tabular}{|c|c|c|c|c|}
\hline \multirow{2}{*}{$\begin{array}{l}\text { Sample: } \\
\text { Years: }\end{array}$} & \multirow{2}{*}{$\begin{array}{c}(1) \\
\text { Full } \\
\text { All }\end{array}$} & \multirow{2}{*}{$\begin{array}{c}(2) \\
\text { Countries } \\
\text { All }\end{array}$} & \multirow{2}{*}{$\begin{array}{c}(3) \\
\text { Introducing a } 1 \\
-1 \text { to } 0\end{array}$} & \multirow{2}{*}{$\begin{array}{c}(4) \\
\text { atent Box } \\
-1 \text { to }+1\end{array}$} \\
\hline & & & & \\
\hline Tax Reduction & $\begin{array}{c}0.241^{* * *} \\
(0.0353)\end{array}$ & $\begin{array}{c}0.484^{* * *} \\
(0.160)\end{array}$ & $\begin{array}{c}1.094^{* * *} \\
(0.135)\end{array}$ & $\begin{array}{l}0.550^{* *} \\
(0.231)\end{array}$ \\
\hline Tax Reduction*Total Apps & $\begin{array}{l}-4.19 \mathrm{e}-05^{* * *} \\
\quad(1.04 \mathrm{e}-05)\end{array}$ & & & \\
\hline Tax Reduction*2-10 Apps & & $\begin{array}{r}-0.158^{* *} \\
(0.0745)\end{array}$ & $\begin{array}{l}-0.155 \\
(0.178)\end{array}$ & $\begin{array}{c}-0.0889 \\
(0.173)\end{array}$ \\
\hline Tax Reduction*11+ Apps & & $\begin{array}{c}-0.425^{* * *} \\
(0.0872)\end{array}$ & $\begin{array}{c}-0.386^{* *} \\
(0.131)\end{array}$ & $\begin{array}{c}-0.478^{* *} \\
(0.162)\end{array}$ \\
\hline CIT & $\begin{array}{c}-0.00534 \\
(0.0621)\end{array}$ & $\begin{array}{c}0.246 \\
(0.240)\end{array}$ & & \\
\hline b-index & $\begin{array}{l}-0.0267 \\
(0.0229)\end{array}$ & $\begin{array}{c}0.102 \\
(0.0974)\end{array}$ & & \\
\hline Family Size & $\begin{array}{c}0.0380 * * * \\
(0.00168)\end{array}$ & $\begin{array}{c}0.0472 * * * \\
(0.00513)\end{array}$ & $\begin{array}{c}0.0540 * * * \\
(0.00363)\end{array}$ & $\begin{array}{c}0.0500 * * * \\
(0.00315)\end{array}$ \\
\hline Codes & $\begin{array}{c}-0.000881^{* * *} \\
(0.000208)\end{array}$ & $\begin{array}{c}-0.00173^{* * *} \\
(0.000482)\end{array}$ & $\begin{array}{c}-0.000623 \\
(0.00103)\end{array}$ & $\begin{array}{c}-0.00277^{*} \\
(0.00127)\end{array}$ \\
\hline Num. Inventors & $\begin{array}{c}-0.00198 * * * \\
(0.000743)\end{array}$ & $\begin{array}{c}0.00585^{* * *} \\
(0.00154)\end{array}$ & $\begin{array}{c}0.00648^{* *} \\
(0.00281)\end{array}$ & $\begin{array}{c}0.00531 \\
(0.00334)\end{array}$ \\
\hline Intl Team & $\begin{array}{l}0.00882^{*} \\
(0.00484)\end{array}$ & $\begin{array}{c}-0.0335^{* * *} * \\
(0.0123)\end{array}$ & $\begin{array}{l}0.00796 \\
(0.0126)\end{array}$ & $\begin{array}{l}0.0163 \\
(0.0165)\end{array}$ \\
\hline Intl App-Inv & $\begin{array}{c}-0.0158 * * * \\
(0.00538)\end{array}$ & $\begin{array}{c}0.0343^{* * *} * \\
(0.00972)\end{array}$ & $\begin{array}{r}-0.00281 \\
(0.0184)\end{array}$ & $\begin{array}{l}-0.0216 \\
(0.0187)\end{array}$ \\
\hline Forward Cites & $\begin{array}{c}0.00232^{* * *} \\
(0.000156)\end{array}$ & $\begin{array}{c}0.00291 * * * \\
(0.000375)\end{array}$ & $\begin{array}{c}0.00267^{* * *} \\
(0.000529)\end{array}$ & $\begin{array}{r}0.00323 * * * \\
(0.000826)\end{array}$ \\
\hline Backward Cites & $\begin{array}{c}-0.00156 * * * \\
(0.000346)\end{array}$ & $\begin{array}{c}-0.00207 * * * \\
(0.000669)\end{array}$ & $\begin{array}{l}-0.00248 \\
(0.00167)\end{array}$ & $\begin{array}{l}-0.00122 \\
(0.00145)\end{array}$ \\
\hline Total Apps. & $\begin{array}{c}-4.43 \mathrm{e}-06^{* * *} \\
(4.65 \mathrm{e}-07)\end{array}$ & $\begin{array}{c}-1.38 \mathrm{e}-05^{* * *} * \\
(2.48 \mathrm{e}-06)\end{array}$ & $\begin{array}{c}-1.30 \mathrm{e}-05^{* * *} \\
(1.36 \mathrm{e}-06)\end{array}$ & $\begin{array}{c}-1.02 \mathrm{e}-05^{* *} \\
(3.92 \mathrm{e}-06)\end{array}$ \\
\hline App. Success & $\begin{array}{l}0.249^{* * *} \\
(0.00523)\end{array}$ & $\begin{array}{l}0.269^{* * *} \\
(0.0238)\end{array}$ & $\begin{array}{l}0.293^{* * *} \\
(0.0327)\end{array}$ & $\begin{array}{l}0.293 * * * \\
(0.0387)\end{array}$ \\
\hline Inv. Success & $\begin{array}{r}0.0599 * * * \\
(0.00366)\end{array}$ & $\begin{array}{c}0.0990^{* * *} \\
(0.0142)\end{array}$ & $\begin{array}{c}0.0836^{* * *} \\
(0.0238)\end{array}$ & $\begin{array}{c}0.0624^{* *} \\
(0.0266)\end{array}$ \\
\hline GDP & $\begin{array}{c}-0.450^{* * *} \\
(0.0686)\end{array}$ & $\begin{array}{c}-0.890 * * * \\
(0.227)\end{array}$ & $\begin{array}{c}-0.00744^{*} \\
(0.00353)\end{array}$ & $\begin{array}{c}-0.0556^{* * * *} \\
(0.00587)\end{array}$ \\
\hline GDP per capita & $\begin{array}{c}0.0325 \\
(0.0678)\end{array}$ & $\begin{array}{c}0.879 * * \\
(0.333)\end{array}$ & $\begin{array}{c}0.0286 \\
(0.0251)\end{array}$ & $\begin{array}{c}-0.0602 * * \\
(0.0216)\end{array}$ \\
\hline $\mathrm{R} \& \mathrm{D}$ & $\begin{array}{c}-0.0410^{* * *} \\
(0.0114)\end{array}$ & $\begin{array}{c}-0.117^{* * *} * \\
(0.0307)\end{array}$ & $\begin{array}{c}0.0388 \\
(0.0635)\end{array}$ & $\begin{array}{l}-0.0312 \\
(0.0641)\end{array}$ \\
\hline Constant & $\begin{array}{c}13.14^{* * *} \\
(1.598)\end{array}$ & $\begin{array}{c}16.01^{* * * *} \\
(4.366)\end{array}$ & $\begin{array}{c}0.202 \\
(0.248)\end{array}$ & $\begin{array}{c}2.330^{* * *} \\
(0.314)\end{array}$ \\
\hline Obs. & 721,982 & 82,269 & 14,071 & 13,508 \\
\hline Adj. $R^{2}$ & 0.096 & 0.117 & 0.128 & 0.113 \\
\hline
\end{tabular}

Notes: Robust standard errors clustered by country-year in parentheses. ${ }^{* * *} \mathrm{p}<0.01,{ }^{* *} \mathrm{p}<0.05,{ }^{*} \mathrm{p}<0.1$. All specifications include country, year, and CPC fixed effects. Applicant success is over prior three years. Inventor success is mean of prior three years. 
Table 14: Types of Patent Boxes

\begin{tabular}{|c|c|c|c|c|}
\hline Box Type: & \multicolumn{2}{|c|}{ Broad } & \multicolumn{2}{|c|}{ Nexus } \\
\hline Patent Box & $\begin{array}{c}0.0673^{* * *} \\
(0.00953)\end{array}$ & $\begin{array}{c}0.0600^{* * *} * \\
(0.00946)\end{array}$ & $\begin{array}{c}0.0189^{* * *} \\
(0.00688)\end{array}$ & $\begin{array}{c}0.0312^{* * *} \\
(0.00762)\end{array}$ \\
\hline Patent Box*Total Apps & $\begin{array}{c}-9.38 \mathrm{e}-06 * * * \\
(2.22 \mathrm{e}-06)\end{array}$ & $\begin{array}{c}-5.93 \mathrm{e}-06 * * * \\
(1.72 \mathrm{e}-06)\end{array}$ & $\begin{array}{c}-8.84 \mathrm{e}-06 * * * \\
(2.15 \mathrm{e}-06)\end{array}$ & $\begin{array}{c}-3.92 \mathrm{e}-05^{* * *} \\
(5.95 \mathrm{e}-06)\end{array}$ \\
\hline Patent Box*Broad & $\begin{array}{c}-0.0591 * * * \\
(0.0112)\end{array}$ & $\begin{array}{c}-0.0431^{* * *} \\
(0.0121)\end{array}$ & & \\
\hline Patent Box*Total Apps*Broad & & $\begin{array}{c}-3.27 \mathrm{e}-05^{* * *} \\
\quad(6.10 \mathrm{e}-06)\end{array}$ & & \\
\hline Patent Box*Nexus & & & $\begin{array}{c}0.0345 * * * \\
(0.0108)\end{array}$ & $\begin{array}{c}0.0160 \\
(0.0114)\end{array}$ \\
\hline Patent Box*Total Apps*Nexus & & & & $\begin{array}{c}3.38 \mathrm{e}-05^{* * *} * \\
(6.11 \mathrm{e}-06)\end{array}$ \\
\hline CIT & $\begin{array}{l}0.00835 \\
(0.0592)\end{array}$ & $\begin{array}{c}0.0135 \\
(0.0581)\end{array}$ & $\begin{array}{c}-0.00616 \\
(0.0604)\end{array}$ & $\begin{array}{l}0.00316 \\
(0.0589)\end{array}$ \\
\hline b-index & $\begin{array}{l}-0.0127 \\
(0.0231)\end{array}$ & $\begin{array}{l}-0.0183 \\
(0.0231)\end{array}$ & $\begin{array}{l}-0.0255 \\
(0.0236)\end{array}$ & $\begin{array}{l}-0.0286 \\
(0.0232)\end{array}$ \\
\hline Family Size & $\begin{array}{c}0.0381^{* * *} * \\
(0.00168)\end{array}$ & $\begin{array}{c}0.0382^{* * *} \\
(0.00168)\end{array}$ & $\begin{array}{c}0.0380 * * * \\
(0.00168)\end{array}$ & $\begin{array}{c}0.0381^{* * *} * \\
(0.00167)\end{array}$ \\
\hline Codes & $\begin{array}{c}-0.000890^{* * *} * \\
(0.000209)\end{array}$ & $\begin{array}{c}-0.000871 * * * \\
(0.000208)\end{array}$ & $\begin{array}{c}-0.000888 * * * \\
(0.000208)\end{array}$ & $\begin{array}{c}-0.000869^{* * *} * \\
(0.000208)\end{array}$ \\
\hline Num. Inventors & $\begin{array}{c}-0.00204 * * * \\
(0.000741)\end{array}$ & $\begin{array}{c}-0.00202^{* * *} \\
(0.000743)\end{array}$ & $\begin{array}{c}-0.00205^{* * *} \\
(0.000741)\end{array}$ & $\begin{array}{c}-0.00202^{* * *} * \\
(0.000744)\end{array}$ \\
\hline Intl Team & $\begin{array}{l}0.00882^{*} \\
(0.00482)\end{array}$ & $\begin{array}{c}0.00608 \\
(0.00463)\end{array}$ & $\begin{array}{l}0.00891^{*} \\
(0.00483)\end{array}$ & $\begin{array}{c}0.00606 \\
(0.00464)\end{array}$ \\
\hline Intl App-Inv & $\begin{array}{c}-0.0158 * * * \\
(0.00536)\end{array}$ & $\begin{array}{r}-0.0121^{* *} \\
(0.00496)\end{array}$ & $\begin{array}{c}-0.0158 * * * \\
(0.00537)\end{array}$ & $\begin{array}{l}-0.0119 * * \\
(0.00497)\end{array}$ \\
\hline Forward Cites & $\begin{array}{c}0.00232 * * * \\
(0.000157)\end{array}$ & $\begin{array}{c}0.00232 * * * \\
(0.000157)\end{array}$ & $\begin{array}{c}0.00232^{* * *} * \\
(0.000157)\end{array}$ & $\begin{array}{c}0.00232 * * * \\
(0.000157)\end{array}$ \\
\hline Backward Cites & $\begin{array}{c}-0.00155^{* * *} * \\
(0.000344)\end{array}$ & $\begin{array}{c}-0.00152^{* * *} \\
(0.000342)\end{array}$ & $\begin{array}{c}-0.00155^{* * *} * \\
(0.000345)\end{array}$ & $\begin{array}{c}-0.00153^{* * *} * \\
(0.000343)\end{array}$ \\
\hline Total Apps. & $\begin{array}{c}-4.38 \mathrm{e}-06^{* * *} \\
(4.61 \mathrm{e}-07)\end{array}$ & $\begin{array}{c}-4.44 \mathrm{e}-06 * * * \\
(4.61 \mathrm{e}-07)\end{array}$ & $\begin{array}{c}-4.42 \mathrm{e}-06^{* * *} \\
(4.64 \mathrm{e}-07)\end{array}$ & $\begin{array}{c}-4.47 \mathrm{e}-06 * * * \\
(4.64 \mathrm{e}-07)\end{array}$ \\
\hline App. Success & $\begin{array}{l}0.249 * * * \\
(0.00526)\end{array}$ & $\begin{array}{l}0.251 * * * \\
(0.00539)\end{array}$ & $\begin{array}{l}0.249 * * * \\
(0.00525)\end{array}$ & $\begin{array}{l}0.251 * * * \\
(0.00538)\end{array}$ \\
\hline Inv. Success & $\begin{array}{c}0.0601 * * * \\
(0.00367)\end{array}$ & $\begin{array}{c}0.0605 * * * \\
(0.00364)\end{array}$ & $\begin{array}{c}0.0601 * * * \\
(0.00367)\end{array}$ & $\begin{array}{c}0.0605 * * * \\
(0.00364)\end{array}$ \\
\hline GDP & $\begin{array}{c}-0.400 * * * \\
(0.0711)\end{array}$ & $\begin{array}{c}-0.389 * * * \\
(0.0714)\end{array}$ & $\begin{array}{c}-0.427 * * * \\
(0.0807)\end{array}$ & $\begin{array}{c}-0.425^{* * *} \\
(0.0793)\end{array}$ \\
\hline GDP per capita & $\begin{array}{l}-0.0242 \\
(0.0696)\end{array}$ & $\begin{array}{c}-0.0304 \\
(0.0693)\end{array}$ & $\begin{array}{c}0.0195 \\
(0.0768)\end{array}$ & $\begin{array}{c}0.0143 \\
(0.0753)\end{array}$ \\
\hline $\mathrm{R} \& \mathrm{D}$ & $\begin{array}{c}-0.0315^{* * *} \\
(0.0113)\end{array}$ & $\begin{array}{c}-0.0284^{* *} \\
(0.0113)\end{array}$ & $\begin{array}{c}-0.0390 * * * \\
(0.0119)\end{array}$ & $\begin{array}{c}-0.0355^{* * *} * \\
(0.0117)\end{array}$ \\
\hline Constant & $\begin{array}{c}10.51^{* * *} \\
(1.370)\end{array}$ & $\begin{array}{c}10.33^{* * *} \\
(1.372)\end{array}$ & $\begin{array}{c}10.74^{* * *} \\
(1.497)\end{array}$ & $\begin{array}{c}10.72^{* * *} \\
(1.474)\end{array}$ \\
\hline Obs. & 719,294 & 719,294 & 719,294 & 719,294 \\
\hline Adj. $R^{2}$ & 0.096 & 0.096 & 0.096 & 0.096 \\
\hline
\end{tabular}

Notes: Robust standard errors clustered by country-year in parentheses. *** $\mathrm{p}<0.01, * * \mathrm{p}<0.05,{ }^{*} \mathrm{p}<0.1$. All specifications include country, year, and CPC fixed effects. Applicant success is over prior three years. Inventor success is mean of prior three years. 
Table 15: Number of Applications

\begin{tabular}{|c|c|c|c|c|c|}
\hline Sample & $\begin{array}{c}(1) \\
\text { Country } \\
(\text { All) }\end{array}$ & $\begin{array}{c}(2) \\
\text { Country } \\
\text { (Single) }\end{array}$ & $\begin{array}{c}(3) \\
\text { Country } \\
(2-10 \mathrm{Apps})\end{array}$ & $\begin{array}{c}(4) \\
\text { Country } \\
(11+\text { Apps })\end{array}$ & $\begin{array}{c}(5) \\
\text { Applicant }\end{array}$ \\
\hline Patent Box & $\begin{array}{c}-0.243^{* * * *} \\
(0.0832)\end{array}$ & $\begin{array}{c}-0.120 \\
(0.0786)\end{array}$ & $\begin{array}{l}0.0258 \\
(0.103)\end{array}$ & $\begin{array}{c}-0.633^{* * *} \\
(0.148)\end{array}$ & $\begin{array}{c}-0.416^{*} \\
(0.246)\end{array}$ \\
\hline Eff. Tax Rate & $\begin{array}{c}-0.780^{* *} \\
(0.370)\end{array}$ & $\begin{array}{c}-0.628^{*} \\
(0.328)\end{array}$ & $\begin{array}{l}-0.135 \\
(0.412)\end{array}$ & $\begin{array}{c}-2.070 * * * \\
(0.648)\end{array}$ & $\begin{array}{l}-0.743 \\
(1.084)\end{array}$ \\
\hline b-index & $\begin{array}{l}-0.287 \\
(0.177)\end{array}$ & $\begin{array}{l}-0.212 \\
(0.162)\end{array}$ & $\begin{array}{l}-0.188 \\
(0.165)\end{array}$ & $\begin{array}{l}-0.197 \\
(0.246)\end{array}$ & $\begin{array}{l}0.0731 \\
(0.416)\end{array}$ \\
\hline GDP & $\begin{array}{c}3.220^{* * *} \\
(0.621)\end{array}$ & $\begin{array}{c}1.916^{* * *} \\
(0.628)\end{array}$ & $\begin{array}{l}1.372^{* *} \\
(0.617)\end{array}$ & $\begin{array}{c}6.479^{* * *} \\
(0.920)\end{array}$ & $\begin{array}{c}8.122^{* * *} \\
(1.965)\end{array}$ \\
\hline GDP per capita & $\begin{array}{l}0.0782 \\
(0.614)\end{array}$ & $\begin{array}{c}0.318 \\
(0.701)\end{array}$ & $\begin{array}{l}1.733^{* *} \\
(0.742)\end{array}$ & $\begin{array}{l}-1.121 \\
(0.934)\end{array}$ & $\begin{array}{c}-4.242^{* *} \\
(1.956)\end{array}$ \\
\hline $\mathrm{R} \& \mathrm{D}$ & $\begin{array}{c}0.261 * * * \\
(0.0595)\end{array}$ & $\begin{array}{c}0.181^{* * *} \\
(0.0613)\end{array}$ & $\begin{array}{c}0.242^{* * *} \\
(0.0693)\end{array}$ & $\begin{array}{c}0.326^{* * *} \\
(0.0936)\end{array}$ & $\begin{array}{c}0.438^{* *} \\
(0.176)\end{array}$ \\
\hline Constant & $\begin{array}{c}-82.99^{* * *} \\
(12.27)\end{array}$ & $\begin{array}{c}-51.08^{* * *} \\
(11.94)\end{array}$ & $\begin{array}{c}-49.45^{* * *} \\
(11.37)\end{array}$ & $\begin{array}{c}-161.2^{* * *} \\
(19.41)\end{array}$ & $\begin{array}{c}-179.7^{* * *} \\
(39.25)\end{array}$ \\
\hline Observations & 375 & 375 & 375 & 375 & 14,300 \\
\hline
\end{tabular}




\section{Oxford University Centre for Business Taxation Working Paper series recent papers}

WP20/01 Richard Collier, Alice Pirlot and John Vella Tax policy and the COVID-19 crisis WP19/16 Alice Pirlot Don't blame it on WTO law: An analysis of the alleged WTO law incompatibility of Destination-Based Taxes

WP19/15 Irem Güçeri and Maciej Albinowski Investment Responses to Tax Policy under Uncertainty

WP19/14 David R. Agrawal and David E. Wildasin Technology and Tax Systems

WP19/13 Alice Pirlot Exploring the Impact of European Union Law on Energy and Environmental Taxation

WP19/12 Michael Devereux How should business profit be taxed? Some thoughts on conceptual developments during the lifetime of the IFS

WP19/11 Sarah Clifford and Panos Mavrokonstantis Tax Enforcement using a Hybrid between Self- and Third-Party Reporting

WP19/10 Miguel Almunia, Irem Guceri, Ben Lockwood, Kimberley Scharf More giving or more givers? The effects of tax incentives on charitable donations in the UK

WP19/09 Itai Grinberg Stabilizing "pillar one" corporate profit reallocation in an uncertain environment

WP19/08 Joel Slemrod, Obeid Ur Rehman, Mazhar Waseem Pecuniary and non-pecuniary motivations for tax compliance: evidence from Pakistan

WP19/07 Enda Hargaden, Barra Roantree Does statutory incidence matter? Earnings responses to social security contributions

WP19/06 Lucie Gadenne, Tushar K. Nandi, Roland Rathelot Taxation and supplier networks: evidence from India

WP19/05 Thiess Buettner, Boryana Madzharova Unit sales and price effects of preannounced consumption tax reforms: micro-level evidence from European VAT

WP19/04 Katarzyna Bilicka, Yaxuan Qi, Jing Xing Debt reallocation in multinational firms: evidence from the UK worldwide debt cap

WP19/03 Reuven Avi-Yonah, Orli Avi-Yonah, Nir Fishbien and Haiyan Xu Bridging the redblue divide: a proposal for US Regional Tax Relief 
WP19/02 Elizabeth Gugl, George R. Zodrow Tax competition and the efficiency of "benefitrelated" business taxes

WP19/01 Michael P Devereux, Alan Auerbach, Michael Keen, Paul Oosterhuis, Wolfgang Schön and John Vella Residual profit allocation by income

WP18/22 Ronny Freier, Martin Simmler and Christian Wittrock Public good provision, commuting and local employment

WP18/21 Christian Wittrock Localization Economies and the Sensitivity of Firm Foundations to Changes in Taxation and Public Expenditures

WP18/20 Nadine Riedel, Martin Simmler and Christian Wittrock Local fiscal policies and their impact on the number and spatial distribution of new firms

WP18/19 Leonie Hug and Martin Simmler How cost-effective is public R\&D in stimulating firm innovation?

WP18/18 Wiji Arulampalam and Andrea Papini Tax Progressivity and Self-Employment Dynamics

WP18/17 Wiji Arulampalam, Michael P Devereux and Federica Liberini Taxes and the Location of Targets

WP18/16 Frank M Fossen, Ray Rees, Davud Rostam-Afschaf and Viktor Steiner How do Entrepreneurial Portfolios Respond to Income Taxation

WP18/15 Sebastian Beer, Ruud de Mooij and Li Liu International Corporate Tax Avoidance: A Review of the Channels, Magnitudes and Blind Spots

WP18/14 Daisy Ogembo Are Presumptive Taxes a Good Option for Taxing Self-Employed Professionals in Developing Countries

WP18/13 Ilan Benshalom The Rise of Inequality and the fall of Tax Equity

WP18/12 Thomas Torslov, Ludwig Weir and Gabriel Zucman The Missing Profits of Nations

WP18/11 Andrea Lassman and Benedikt Zoller-Rydzek Decomposing the Margins of Transfer Pricing

WP18/10 Travis Chow, Jeffrey L Hoopes and Edward L Maydew US Firms on Foreign (tax) Holidays

WP18/09 Claudio Agostini, Juan Pablo Atal and Andrea Repetto Firms Response to Tax Enforcement through Audits 
WP18/08 Mazhar Waseem Information, Asymmetric Incentives or Withholding? Understanding the Self-Enforcement of Value-Added-Tax

WP18/07 Matthew Smith, Danny Yagan, Owen Zidar and Eric Zwick Capitalists in the twenty-first century

WP18/06 Daniel Shaviro The new non-territorial U.S international tax system

WP18/05 Eric M Zolt Tax Treaties and Developing Countries

WP18/04 Anne Brockmeyer, Marco Hernandez, Stewart Kettle and Spencer Smith Casting a wider tax net: Experimental evidence from Costa Rica

WP18/03 Ruud de Mooij and Li Liu At a cost:the real effects of transfer pricing regulations

WP18/02 Rita de la Feria Tax fraud and the rule of law

WP18/01 Eddy Hiu Fung Tam Behavioural response to time notches in transaction tax: Evidence from stamp duty in Hong Kong and Singapore

WP17/19 Michael P. Devereux, Giorgia Maffini and Jing Xing Corporate tax incentives \& capital structure: New evidence from UK firm-level tax returns

WP17/18 Sarah Clifford Taxing Multinationals beyond borders: financial and locational responses to CFC rules

WP17/17 Dominik von Hagen and Axel Prettl Controlled foreign corporation rules and crossborder M\&A activity

WP17/16 Marie Lamensch Destination based taxation of corporate profits - preliminary findings regarding tax collection in cross-border situations

WP17/15 Li Liu Tim Schmidt-Eisenlohr and Dongxian Guo International transfer pricing and tax avoidance: Evidence from linked trade-tax statistics in the UK.

WP17/14 Katarzyna Habu How much tax do companies pay in the UK?

WP17/13 Katarzyna Habu How aggressive are foreign multinational companies in reducing their corporation tax liability?

WP17/12 Edward D. Kleinbard The right tax at the right time

WP17/11 Aaron Flaaen The role of transfer prices in profit-shifting by U.S. multinational firms: Evidence from the 2004 Homeland Investment Act

WP17/10 Ruud de Mooij and Li Liu At a cost: The real effect of transfer pricing regulations on multinational investments 
WP17/09 Wei Cui Taxation without information: The institutional foundations of modern tax collection

WP17/08 John Brooks The definitions of income

WP17/07 Michael P. Devereux and John Vella Implications of Digitalization for International Corporation Tax Reform

WP17/06 Richard Collier and Michael P. Devereux The Destination-Based Cash Flow Tax and the Double Tax Treaties

WP17/05 Li Liu Where does multinational investment go with Territorial Taxation

WP17/04 Wiji Arulampalam, Michael P Devereux and Federica Liberini Taxes and Location of Targets

WP17/03 Johannes Becker and Joachim Englisch A European Perspective on the US plans for a Destination based cash flow tax

WP17/02 Andreas Haufler, Mohammed Mardan and Dirk Schindler Double tax discrimination to attract FDI and fight profit shifting: The role of CFC rules

WP17/01 Alan Auerbach, Michael P. Devereux, Michael Keen and John Vella Destinationbased cash flow taxation

WP16/14 Anzhela Cédelle The EU Anti-Tax Avoidance Directive: A UK Perspective

WP16/13 Michael Devereux Measuring corporation tax uncertainty across countries:

Evidence from a cross-country survey

WP16/12 Andreas Haufler and Ulf Maier Regulatory competition in capital standards with selection effects among banks

WP16/11 Katarzyna Habu Are financing constraints binding for investment? Evidence from natural experiment

WP 16/10 Li Liu and Ben Lockwood VAT notches, voluntary registration and bunching: Theory and UK evidence

WP 16/09 Harry Grubert and Roseanne Altshuler Shifting the burden of taxation from the corporate to the personal level and getting the corporate tax rate down to 15 percent

WP 16/08 Margaret K McKeehan and George R Zodrow Balancing act: weighing the factors affecting the taxation of capital income in a small open economy

WP 16/07 Michael P Devereux and Li Liu Stimulating investment through incorporation 
WP 16/06 Stephen R Bond and Irem Guceri R\&D and productivity: Evidence from large UK establishments with substantial R\&D activities

WP16/05 Tobias Böhm, Nadine Riedel and Martin Simmler Large and influential: firm size and governments' corporate tax rate choice?

WP16/04 Dhammika Dharmapala The economics of corporate and business tax reform

WP 16/03 Rita de la Feria EU VAT principles as interpretative aids to EU VAT rules: the inherent paradox

WP 16/02 Irem Guceri Will the real R\&D employees please stand up? Effects of tax breaks on firm level outcomes

WP 16/01 Giorgia Maffini, Jing Xing and Michael P Devereux The impact of investment incentives: evidence from UK corporation tax returns

WP 15/33 Anzhela Cédelle Enhanced co-operation: a way forward for tax harmonisation in the EU?

WP 15/32 James Mahon and Eric Zwick Do experts help firms optimise?

WP 15/31 Robin Boadway, Motohiro Sato and Jean-François Tremblay Cash-flow business taxation revisited: bankruptcy, risk aversion and asymmetric information

WP 15/30 Martin Simmler Do multinational firms invest more? On the impact of internal debt financing and transfer pricing on capital accumulation

WP 15/29 Daniel Shaviro The crossroads versus the seesaw: getting a 'fix' on recent international tax policy developments

WP 15/28 Zhonglan Dai, Douglas A Shackelford, Yue (Layla) Ying and Harold H Zhang Do companies invest more after shareholder tax cuts?

WP 15/27 Martin Ruf and Julia Schmider Who bears the cost of taxing the rich? An empirical study on CEO pay

WP 15/26 Eric Orhn The corporate investment response to the domestic production activities deduction

WP 15/25 Li Liu International taxation and MNE investment: evidence from the UK change to territoriality

WP 15/24 Edward D Kleinbard Reimagining capital income taxation 
WP 15/23 James R Hines Jr, Niklas Potrafke, Marina Riem and Christoph Schinke Inter vivos transfers of ownership in family firms

WP 15/22 Céline Azémar and Dhammika Dharmapala Tax sparing agreements, territorial tax reforms, and foreign direct investment

WP 15/21 Wei Cui A critical review of proposals for destination-based cash-flow corporate taxation as an international tax reform option

WP 15/20 Andrew Bird and Stephen A Karolyi Governance and taxes: evidence from regression discontinuity

WP 15/19 Reuven Avi-Yonah Reinventing the wheel: what we can learn from the Tax Reform Act of 1986

WP 15/18 Annette Alstadsæter, Salvador Barrios, Gaetan Nicodeme, Agnieszka Maria Skonieczna and Antonio Vezzani Patent boxes design, patents, location and local R\&D

WP 15/17 Laurent Bach Do better entrepreneurs avoid more taxes?

WP 15/16 Nadja Dwenger, Frank M Fossen and Martin Simmler From financial to real economic crisis: evidence from individual firm-bank relationships in Germany

WP 15/15 Giorgia Maffini and John Vella Evidence-based policy-making? The Commission's proposal for an FTT

WP 15/14 Clemens Fuest and Jing Xing How can a country 'graduate' from procyclical fiscal policy? Evidence from China?

WP 15/13 Richard Collier and Giorgia Maffini The UK international tax agenda for business and the impact of the OECD BEPS project

WP 15/12 Irem Guceri and Li Liu Effectiveness of fiscal incentives for R\&D: quasiexperimental evidence

WP 15/11 Irem Guceri Tax incentives and R\&D: an evaluation of the 2002 UK reform using micro data

WP 15/10 Rita de la Feria and Parintira Tanawong Surcharges and penalties in UK tax law

WP 15/09 Ernesto Crivelli, Ruud de Mooij, Michael Keen Base erosion, profit-shifting and developing countries

WP 15/08 Judith Freedman Managing tax complexity: the institutional framework for tax policy-making and oversight 
WP 15/07 Michael P Devereux, Giorgia Maffini and Jing Xing Corporate tax incentives and capital structure: empirical evidence from UK tax returns

WP 15/06 Li Liu and Ben Lockwood VAT notches

WP 15/05 Clemens Fuest and Li Liu Does ownership affect the impact of taxes on firm behaviour? Evidence from China.

WP 15/04 Michael P Devereux, Clemens Fuest and Ben Lockwood The taxation of foreign profits: a unified view

WP 15/03 Jitao Tang and Rosanne Altshuler The spillover effects of outward foreign direct investment on home countries: evidence from the United States

WP 15/02 Juan Carlos Suarez Serrato and Owen Zidar Who benefits from state corporate tax cuts? A local labour markets approach with heterogeneous firms

WP 15/01 Ronald B Davies, Julien Martin, Mathieu Parenti and Farid Toubal Knocking on Tax Haven's Door: multinational firms and transfer pricing 